\title{
Review Article \\ Chemokines in Chronic Liver Allograft Dysfunction Pathogenesis and Potential Therapeutic Targets
}

\author{
Bin Liu, ${ }^{1}$ Jing Li, ${ }^{2}$ and Lu-Nan Yan $^{3}$ \\ ${ }^{1}$ Department of General Surgery, General Hospital of Tianjin Medical University, Tianjin 300052, China \\ ${ }^{2}$ Department of Anesthesiology, General Hospital of Tianjin Medical University, Tianjin 300052, China \\ ${ }^{3}$ Department of General Surgery, West China Hospital, Sichuan University, Chengdu, Sichuan 610041, China
}

Correspondence should be addressed to Bin Liu; surgeryliubin@163.com

Received 4 August 2013; Accepted 3 October 2013

Academic Editor: Basak Kayhan

Copyright ( 2013 Bin Liu et al. This is an open access article distributed under the Creative Commons Attribution License, which permits unrestricted use, distribution, and reproduction in any medium, provided the original work is properly cited.

\begin{abstract}
Despite advances in immunosuppressive drugs, long-term success of liver transplantation is still limited by the development of chronic liver allograft dysfunction. Although the exact pathogenesis of chronic liver allograft dysfunction remains to be established, there is strong evidence that chemokines are involved in organ damage induced by inflammatory and immune responses after liver surgery. Chemokines are a group of low-molecular-weight molecules whose function includes angiogenesis, haematopoiesis, mitogenesis, organ fibrogenesis, tumour growth and metastasis, and participating in the development of the immune system and in inflammatory and immune responses. The purpose of this review is to collect all the research that has been done so far concerning chemokines and the pathogenesis of chronic liver allograft dysfunction and helpfully, to pave the way for designing therapeutic strategies and pharmaceutical agents to ameliorate chronic allograft dysfunction after liver transplantation.
\end{abstract}

\section{Introduction}

Chronic liver allograft dysfunction is a leading cause of patient morbidity and late allograft loss after liver transplantation. The loss of approximately 2000 liver grafts each year results in chronic allograft dysfunction [1]. Liver allograft biopsy in patients who survive longer than 5 years shows that $37 \%$ of recipients present with chronic liver allograft dysfunction [2].

The pathological hallmarks of end stage chronic liver allograft dysfunction include hepatocyte necrosis, hepatic arterial proliferative occlusive disease, bile duct disappearance, and eventually liver fibrosis [3]. That pathological changes usually precede functional deterioration in cases of chronic liver allograft dysfunction is characterized [3]. Treatment options in patients with advanced chronic liver allograft dysfunction are limited because of the diffuse nature of the disease. The currently available drug treatments are ineffective. Additionally, retransplantation has limited applicability and success because of donor availability. Hence, chronic liver allograft dysfunction still is a common and frequently fatal, yet poorly treatable, complication of liver transplantation.
Although the pathogenesis of chronic liver allograft dysfunction is not completely defined, it is believed that the histopathologic changes in this patient population can be attributed to early allograft dysfunction [4], acute or chronic rejection $[5,6]$, de novo or recurrent autoimmune disease [7], de novo or recurrent viral hepatitis [3], drugs toxicity $[8,9]$, late effects of ischemia/reperfusion (I/R) injury [10] or ischemictype biliary lesions [11, 12], and other recurrent diseases [13]. Causes of chronic liver allograft dysfunction are variable and are shown in Table 1. The molecular mechanisms of chronic liver allograft dysfunction are still unclear. Several reports have shown that chronic liver allograft dysfunction is caused by repeated episodes of chemotactic mediated injury to the liver graft $[14,15]$. And these forms of injury are inflicted on the allograft throughout all stages of transplantation [16].

Chemokines are a group of low-molecular-weight (8 to $14 \mathrm{kDa}$ ) [17] cytokines of which their common properties are to induce inflammatory cells migration and regulate inflammatory responses. However, recent studies show that chemokines impinge on many facets of biology including angiogenesis, haematopoiesis, mitogenesis, tumour growth and 
TABLE 1: Causes of chronic liver allograft dysfunction.

\begin{tabular}{|c|c|c|}
\hline & Causes & Histopathologic changes and diagnosis \\
\hline \multirow{5}{*}{ Immunological } & Early allograft dysfunction & $\begin{array}{l}\text { Early high transaminases persistent cholestasis and prolonged coagulopathy [4] } \\
\text { acute hepatocellular damage or death. }\end{array}$ \\
\hline & Acute rejection & $\begin{array}{l}\text { Predominantly mononuclear portal inflammation containing neutrophils, } \\
\text { lymphocytes, and eosinophils; inflammatory bile duct damage; and portal or central } \\
\text { venous subendothelial inflammation or perivenular inflammation [22]. }\end{array}$ \\
\hline & Chronic rejection & $\begin{array}{l}\text { A majority of small bile ducts damage bile duct loss affecting }>50 \% \text { of the portal } \\
\text { tracts and foam cell obliterative arteriopathy }[22] .\end{array}$ \\
\hline & Chronic hepatitis & $\begin{array}{l}\text { The presence of a portal and lobular mononuclear infiltrates in the absence of } \\
\text { rejection or the graft damage caused by viral infection [3]. }\end{array}$ \\
\hline & $\begin{array}{l}\text { De novo or recurrent } \\
\text { autoimmune hepatitis }\end{array}$ & $\begin{array}{l}\text { Significant titers }(\geq 1: 160) \text { of smooth muscle antibodies and antinuclear antibodies } \\
\text { interface hepatitis with portal lymphocytic infiltrates hypergammaglobulinemia } \\
\text { and exclusion of viral infection or drug-induced hepatitis }[23,24] \text {. }\end{array}$ \\
\hline Viral & $\begin{array}{l}\text { De novo or recurrent viral } \\
\text { hepatitis (HBV, HCV) }\end{array}$ & $\begin{array}{l}\text { The portal inflammation tends to be more diffusely distributed throughout the } \\
\text { portal tracts; lymphocytic cholangitis is limited to a minority of bile ducts [25]. }\end{array}$ \\
\hline \multirow[t]{2}{*}{ Ischemia } & Late effects of I/R injury & $\begin{array}{l}\text { Hepatocytes and sinusoidal endothelial cells damage adhesion and aggregation of } \\
\text { neutrophils and platelets in the sinusoids sinusoidal narrowing and elevated liver } \\
\text { aminotransferase enzymes [26]. }\end{array}$ \\
\hline & $\begin{array}{l}\text { Ischemic-type biliary } \\
\text { lesions }\end{array}$ & $\begin{array}{l}\text { The complete biliary system is affected or only the major extrahepatic bile ducts are } \\
\text { involved. Epithelial and muscular necrosis of the biliary system and periductal } \\
\text { connective tissue well preserved [27]. }\end{array}$ \\
\hline Toxic & Drugs and other toxins & $\begin{array}{l}\text { Changes are usually mild and nonspecific like hepatitis, cholestasis, nodular } \\
\text { regenerative hyperplasia, and veno-occlusive disease (sinusoidal congestion) or } \\
\text { centrizonal necrosis [8]. }\end{array}$ \\
\hline \multirow{4}{*}{ Recurrent disease } & $\begin{array}{l}\text { Idiopathic } \\
\text { posttransplantation } \\
\text { hepatitis }\end{array}$ & $\begin{array}{l}\text { Bile duct damage and venous endothelial inflammation chronic hepatitis that } \\
\text { cannot be ascribed to a particular cause or presence of bridging fibrosis or cirrhosis } \\
\text { [28]. }\end{array}$ \\
\hline & Recurrent PSC & $\begin{array}{l}\text { Biliary strictures presence of mild portal edema mild nonspecific pericholangitis } \\
\text { lamellar periductal edema concentric periductal fibrosis or biliary gestalt [29]. }\end{array}$ \\
\hline & Recurrent $\mathrm{PBC}$ & $\begin{array}{l}\text { Noninfectious granulomatous cholangitis in the proper setting presence of } \\
\text { antimitochondrial antibodies and absence of other causes such as infections and } \\
\text { biliary strictures [30]. }\end{array}$ \\
\hline & $\begin{array}{l}\text { Alcoholic and nonalcoholic } \\
\text { steatohepatitis }\end{array}$ & $\begin{array}{l}\text { Macrovesicular steatosis Mallory's hyaline ballooning cell degeneration } \\
\text { perisinusoidal fibrosis and scattered neutrophilic inflammation }[31,32] \text {. }\end{array}$ \\
\hline
\end{tabular}

HBV: hepatitis B virus; HCV: hepatitis C virus; I/R injury: ischemia reperfusion injury; PSC: primary sclerosing cholangitis; PBC: primary biliary cirrhosis.

metastasis $[14,18]$, and participating in the development of the immune system and in innate and acquired immune responses $[19,20]$. Dysregulated expression of chemokines and their receptors is involved in the pathogenesis of many human diseases including chronic inflammatory diseases, autoimmune diseases, immunodeficiency, and cancer. Furthermore, chemokines are essential mediators for attracting immune cells and for activating nonparenchymal liver cells [21]. And there is also emerging evidence that these chemokines and their receptors are linked with chronic liver allograft dysfunction development in animal studies [16].

For their involvement in a number of pathological processes, chemokines and their receptors represent important pharmaceutical targets for many diseases [65]. In addition, genetically recombinated/engineered small-molecule chemokine or chemokine inhibitors are emerging in reports both in the literature and at international conferences. In this review we will outline the recent progress in chemokines research with regard to the pathogenesis and development of chronic allograft dysfunction after liver transplantation. Each class of chemokines is discussed separately in this paper.

\section{Chemokine Superfamily}

Since the first member of chemokines/cytokines, platelet factor 4 (PF-4/CXCL4), being discovered in 1955 [66], the family members of chemokines are more than 50 now. Because these molecules are closely related in structure and function, enormous chemokines and chemokine receptors were newly discovered in recent years. According to the presence of a conserved cysteine residue at the $\mathrm{NH}_{2}$ terminus [67], the chemokine superfamily is divided into four subfamilies: C, CC, $\mathrm{CXC}$, and $\mathrm{CX}_{3} \mathrm{C}$. The first and third cysteines are missing in the $\mathrm{C}$ subfamily, while these two cysteines are adjacent in $\mathrm{CC}$ chemokines. In the CXC subfamily, one amino acid separates the first two cysteines, while in $\mathrm{CX}_{3} \mathrm{C}$ chemokines, three amino acids between the two cysteines. Based on the presence or absence of a three-amino-acid sequence ELR, comprising glutamine $(\mathrm{E})$, leucine $(\mathrm{L})$ and arginine $(\mathrm{R})$, adjacent to the CXC motif near the $\mathrm{NH}_{2}$ terminal, the CXC family is further subdivided into ELR-positive and ELR-negative CXC chemokines. A possible new type of CX chemokine, which lacks one of the two N-terminus cysteines but retains the third and 
TABLE 2: Chemokines involved in the pathogenesis of liver disease.

\begin{tabular}{|c|c|c|c|}
\hline Chemokine & Location in the liver & Function & $\begin{array}{l}\text { Receptors and their } \\
\text { distribution }\end{array}$ \\
\hline \multicolumn{4}{|c|}{ CXC subfamily } \\
\hline CXCL1 & $\begin{array}{l}\text { Hepatocytes, Kupffer cells, } \\
\text { activated stellate cells; and } \\
\text { endothelial cells }[33,34]\end{array}$ & $\begin{array}{l}\text { Neutrophil migration, innate immunity, acute } \\
\text { inflammation, and angiogenesis }\end{array}$ & $\begin{array}{l}\text { CXCR1: PMN, monocytes, } \\
\text { and mast cells } \\
\text { CXCR2: PMN, monocytes, } \\
\text { and mast cells }\end{array}$ \\
\hline CXCL2 & $\begin{array}{l}\text { Hepatocytes, Kupffer cells, } \\
\text { activated stellate cells; and } \\
\text { endothelial cells }[34,35]\end{array}$ & $\begin{array}{l}\text { Neutrophil migration, innate immunity, acute } \\
\text { inflammation, and angiogenesis }\end{array}$ & $\begin{array}{l}\text { CXCR2: PMN, monocytes, } \\
\text { and mast cells }\end{array}$ \\
\hline CXCL3 & $\begin{array}{l}\text { Hepatocytes, Kupffer cells, } \\
\text { activated stellate cells, and } \\
\text { endothelial cells }[33,34]\end{array}$ & $\begin{array}{l}\text { Neutrophil migration, innate immunity, acute } \\
\text { inflammation, and angiogenesis }\end{array}$ & $\begin{array}{l}\text { CXCR2: PMN, monocytes, } \\
\text { and mast cells }\end{array}$ \\
\hline CXCL4 & $\begin{array}{l}\text { Sinusoidal endothelium, } \\
\text { platelets, NK cells, T cells, and } \\
\text { neutrophils [36] }\end{array}$ & $\begin{array}{l}\text { Chemotactic for neutrophils, monocytes, and } \\
\text { fibroblasts }\end{array}$ & $\begin{array}{l}\text { CXCR3: memory T cells, Th1, } \\
\text { Th2, Th17, and Treg, NKT }\end{array}$ \\
\hline CXCL4L1 & Thrombin-stimulated platelets [37] & $\begin{array}{l}\text { Angiogenesis and } \\
\text { antitumoral chemokine }\end{array}$ & $\begin{array}{l}\text { CXCR3: memory T cells, Th1, } \\
\text { Th2, Th17, Treg, and NKT }\end{array}$ \\
\hline CXCL5 & $\begin{array}{l}\text { Hepatocytes, Kupffer cells, and } \\
\text { endothelial cells [33] }\end{array}$ & $\begin{array}{l}\text { Neutrophil migration, innate immunity, acute } \\
\text { inflammation, and angiogenesis }\end{array}$ & $\begin{array}{l}\text { CXCR2: PMN, monocytes, } \\
\text { and mast cells }\end{array}$ \\
\hline CXCL6 & $\begin{array}{l}\text { Microvascular endothelial cells } \\
\text { [38] }\end{array}$ & Neutrophil migration and innate immunity & $\begin{array}{l}\text { CXCR1: PMN, monocytes, } \\
\text { and mast cells } \\
\text { CXCR2: PMN, monocytes, } \\
\text { and mast cells }\end{array}$ \\
\hline CXCL7 & Platelets [39] & $\begin{array}{l}\text { Angiogenesis, innate immunity, neutrophil } \\
\text { migration, and regenerating vascular integrity } \\
\text { after injury }\end{array}$ & $\begin{array}{l}\text { CXCR1: PMN, monocytes, } \\
\text { and mast cells } \\
\text { CXCR2: PMN, monocytes, } \\
\text { and mast cells }\end{array}$ \\
\hline CXCL8 & $\begin{array}{l}\text { Endothelial cells, Kupffer cells, } \\
\text { biliary epithelial cells, and stellate } \\
\text { cells [34] }\end{array}$ & $\begin{array}{l}\text { Innate immunity, neutrophil migration, and } \\
\text { angiogenesis }\end{array}$ & $\begin{array}{l}\text { CXCR1: PMN, monocytes, } \\
\text { and mast cells } \\
\text { CXCR2: PMN, monocytes, } \\
\text { and mast cells }\end{array}$ \\
\hline CXCL9 & Sinusoidal epithelial cells [40] & $\begin{array}{l}\text { Th1, Th2, Th17, and Treg recruitment and } \\
\text { adaptive immunity }\end{array}$ & $\begin{array}{l}\text { CXCR3: memory T cells, Th1, } \\
\text { Th2, Th17, Treg, and NKT } \\
\text { CCR3: eosinophils and } \\
\text { basophils }\end{array}$ \\
\hline CXCL10 & $\begin{array}{l}\text { Hepatocytes and liver sinusoids } \\
{[15]}\end{array}$ & $\begin{array}{l}\text { Th1, Th2, Th17, and Treg recruitment and } \\
\text { adaptive immunity }\end{array}$ & $\begin{array}{l}\text { CXCR3: memory T cells, Th1, } \\
\text { Th2, Th17, Treg, and NKT } \\
\text { CCR3: eosinophils and } \\
\text { basophils }\end{array}$ \\
\hline CXCL11 & Liver sinusoids [15] & $\begin{array}{l}\text { Th1, Th2, Th17, and Treg recruitment and } \\
\text { adaptive immunity }\end{array}$ & $\begin{array}{l}\text { CXCR3: memory T cells, Th1, } \\
\text { Th2, Th17, Treg, and NK } \\
\text { CCR3: eosinophils and } \\
\text { basophils } \\
\text { CCR5: monocytes, Th1 cells, } \\
\text { and NK }\end{array}$ \\
\hline CXCL12 & Biliary epithelium [15] & Stem cell migration and B-cell lymphopoiesis & $\begin{array}{l}\text { CXCR4: } \mathrm{T} \text { and B cells, } \\
\text { monocytes, stem cells, and } \\
\text { NKT }\end{array}$ \\
\hline CXCL13 & $\begin{array}{l}\text { Lymphocytes within } \\
\text { microenvironments [41] }\end{array}$ & $\begin{array}{l}\text { B-cell homing in lymphoid organ and liver } \\
\text { and T-cell homing in the liver }\end{array}$ & $\begin{array}{l}\text { CXCR5: B cells } \\
\text { CXCR3: memory T cells, Th1, } \\
\text { Th2, Th17, Treg and NKT }\end{array}$ \\
\hline
\end{tabular}


TABLE 2: Continued.

\begin{tabular}{|c|c|c|c|}
\hline Chemokine & Location in the liver & Function & $\begin{array}{l}\text { Receptors and their } \\
\text { distribution }\end{array}$ \\
\hline CXCL14 & Macrophage and neutrophil [42] & $\begin{array}{l}\text { Recruitment of monocytes/macrophages to } \\
\text { the liver }\end{array}$ & Unknown \\
\hline CXCL16 & $\begin{array}{l}\text { Liver sinusoids biliary epithelium } \\
\text { [15] }\end{array}$ & $\begin{array}{l}\text { T-cell migration, recruitment of CD } 4+\mathrm{T} \text { cells, } \\
\text { and CD } 8+\mathrm{T} \text { cells and B cells into the liver }\end{array}$ & $\begin{array}{l}\text { CXCR6: memory T cells, Th1, } \\
\text { NK and NKT }\end{array}$ \\
\hline CXCL17 & $\begin{array}{l}\text { Endothelial cells and } \\
\text { hepatocellular carcinoma (HCC) } \\
\text { cells [43] }\end{array}$ & $\begin{array}{l}\text { Chemoattract DC and monocytes, } \\
\text { angiogenesis, and carcinogenesis }\end{array}$ & Unknown \\
\hline \multicolumn{4}{|l|}{ CC subfamily } \\
\hline CCL1 & $\begin{array}{l}\text { Hepatocytes, hepatic stellate cells, } \\
\text { endothelium, and Kupffer cells } \\
{[44]}\end{array}$ & T-cell trafficking and Th2 response & $\begin{array}{l}\text { CCR8: monocytes, Th2, Treg } \\
\text { and NK }\end{array}$ \\
\hline CCL2 & $\begin{array}{l}\text { Hepatocytes, Kupffer cells, and } \\
\text { stellate cells [44] }\end{array}$ & $\begin{array}{l}\text { Th1 inflammation, } \mathrm{T} \text {-cell and monocyte } \\
\text { migration, and innate and adaptive immunity }\end{array}$ & $\begin{array}{l}\text { CCR2: monocytes, memory T } \\
\text { cells, basophils and pDC }\end{array}$ \\
\hline CCL3 & $\begin{array}{l}\text { Portal vessels, biliary epithelium, } \\
\text { and sinusoidal endothelium } \\
{[45,46]}\end{array}$ & $\begin{array}{l}\text { T-cell and monocyte migration, innate and } \\
\text { adaptive immunity, inflammation,Th1 } \\
\text { response, HIV infection, and hypersensitivity }\end{array}$ & $\begin{array}{l}\text { CCR1: monocytes, memory T } \\
\text { cells, Th1 and NK } \\
\text { CCR5: monocytes, Th1 cells } \\
\text { and NK }\end{array}$ \\
\hline CCL4 & $\begin{array}{l}\text { Portal vessels, biliary epithelium, } \\
\text { and sinusoidal endothelium [15] }\end{array}$ & $\begin{array}{l}\text { Th1 response, adaptive immunity, } \\
\text { inflammation, HIV infection }\end{array}$ & $\begin{array}{l}\text { CCR5: monocytes, Th1 cells } \\
\text { and NK }\end{array}$ \\
\hline CCL5 & $\begin{array}{l}\text { Portal vessels, platelets, T-cells, } \\
\text { macrophages, liver-derived } \\
\text { dendritic cells, and Kupffer cells } \\
{[15]}\end{array}$ & $\begin{array}{l}\mathrm{T} \text { cell and monocyte migration, innate and } \\
\text { adaptive immunity, inflammation, Th1 } \\
\text { response, and HIV infection, and } \\
\text { hypersensitivity }\end{array}$ & $\begin{array}{l}\text { CCR1: monocytes, memory T } \\
\text { cells, Th1 and NK } \\
\text { CCR3: eosinophils and } \\
\text { basophils } \\
\text { CCR5: monocytes, Th1 cells } \\
\text { and NK }\end{array}$ \\
\hline CCL7 & $\begin{array}{l}\text { Portal vessels, monocytes, } \\
\text { endothelial cells, smooth muscle } \\
\text { cells, and human CD34 cells [47] }\end{array}$ & $\begin{array}{l}\text { T-cell, NK cells, dendritic cells, basophils, } \\
\text { eosinophils, and monocyte migration, innate } \\
\text { and adaptive immunity, Thl inflammation, } \\
\text { and } \\
\text { hypersensitivity }\end{array}$ & $\begin{array}{l}\text { CCR1: monocytes, memory T } \\
\text { cells, Th1, and NK } \\
\text { CCR2: monocytes, memory T } \\
\text { cells, basophils and pDC } \\
\text { CCR3: eosinophils and } \\
\text { basophils } \\
\text { CCR5: monocytes, Th1 cells, } \\
\text { and NK }\end{array}$ \\
\hline CCL8 & $\begin{array}{l}\text { Portal and vascular } \\
\text { endothelium [47] }\end{array}$ & $\begin{array}{l}\text { T-cell and monocyte migration, innate and } \\
\text { adaptive immunity, Thl inflammation, } \\
\text { hypersensitivity, and HIV infection }\end{array}$ & $\begin{array}{l}\text { CCR1: monocytes, memory T } \\
\text { cells, Th1, and NK } \\
\text { CCR2: monocytes, memory T } \\
\text { cells, basophils, and pDC } \\
\text { CCR3: eosinophils and } \\
\text { basophils } \\
\text { CCR5: monocytes, Th1 cells, } \\
\text { and NK }\end{array}$ \\
\hline CCL11 & Foetal liver [48] & $\begin{array}{l}\text { Eosinophil and basophil migration, allergic } \\
\text { inflammation, and Th2 response }\end{array}$ & $\begin{array}{l}\text { CCR2: monocytes, memory T } \\
\text { cells, basophils, and pDC } \\
\text { CCR3: eosinophils and } \\
\text { basophils } \\
\text { CCR5: monocytes, Th1 cells, } \\
\text { and NK } \\
\text { CXCR3: memory T cells, Th1, } \\
\text { Th2, Th17, Treg, and NKT }\end{array}$ \\
\hline CCL12 & Kupffer cells [49] & $\begin{array}{l}\text { Monocytes, T-cell and eosinophils migration, } \\
\text { and allergic inflammation }\end{array}$ & $\begin{array}{l}\text { CCR2: monocytes, memory T } \\
\text { cells, basophils, and DC }\end{array}$ \\
\hline
\end{tabular}


TABLE 2: Continued.

\begin{tabular}{|c|c|c|c|}
\hline Chemokine & Location in the liver & Function & $\begin{array}{l}\text { Receptors and their } \\
\text { distribution }\end{array}$ \\
\hline CCL13 & $\begin{array}{l}\text { Epithelial and endothelial cells } \\
\text { [50] }\end{array}$ & $\begin{array}{l}\text { T-cell and monocyte migration, innate and } \\
\text { adaptive immunity, and Th1 inflammation }\end{array}$ & $\begin{array}{l}\text { CCR1: monocytes, memory T } \\
\text { cells, Th1, and NK } \\
\text { CCR2: monocytes, memory T } \\
\text { cells, basophils, and pDC } \\
\text { CCR3: eosinophils and } \\
\text { basophils }\end{array}$ \\
\hline CCL14 & Widely in liver and plasma [14] & $\begin{array}{l}\text { T-cell and monocyte migration, } \\
\text { hypersensitivity, innate and adaptive } \\
\text { immunity, and inflammation }\end{array}$ & $\begin{array}{l}\text { CCR1: monocytes, memory T } \\
\text { cells, Th1, and NK } \\
\text { CCR3: eosinophils and } \\
\text { basophils } \\
\text { CCR5: monocytes, Th1 cells, } \\
\text { and NK }\end{array}$ \\
\hline CCL15 & Widely in liver [51] & $\begin{array}{l}\text { T-cell, eosinophil, basophil, and monocyte } \\
\text { migration, Th2 response, hypersensitivity, } \\
\text { innate and adaptive immunity, and allergic } \\
\text { inflammation }\end{array}$ & $\begin{array}{l}\text { CCR1: monocytes, memory T } \\
\text { cells, Th1, and NK } \\
\text { CCR3: eosinophils and } \\
\text { basophils }\end{array}$ \\
\hline CCL16 & $\begin{array}{l}\text { Hepatocytes and biliary epithelial } \\
\text { cells [52] }\end{array}$ & $\begin{array}{l}\text { T-cell, eosinophil, basophil, and monocyte } \\
\text { migration, Th2 response, hypersensitivity, } \\
\text { innate and adaptive immunity, and allergic } \\
\text { inflammation }\end{array}$ & $\begin{array}{l}\text { CCR1: monocytes, memory T } \\
\text { cells, Th1, and NK } \\
\text { CCR3: eosinophils and } \\
\text { basophils }\end{array}$ \\
\hline CCL17 & $\begin{array}{l}\text { Keratinocytes, fibroblasts, } \\
\text { stimulated monocytes, and certain } \\
\text { DC [53] }\end{array}$ & $\begin{array}{l}\text { T-cell and monocyte migration, allergic } \\
\text { inflammation, and Treg retention }\end{array}$ & $\begin{array}{l}\text { CCR4: Th2 cells, Treg } \\
\text { eosinophils, basophils, DC, } \\
\text { and Treg }\end{array}$ \\
\hline CCL18 & $\begin{array}{l}\text { Portal area of livers with hepatitis } \\
\mathrm{C} \text { but not in normal livers }[54]\end{array}$ & Lymphocytes and immature DC activation & $\begin{array}{l}\text { CCR3: eosinophils and } \\
\text { basophils }\end{array}$ \\
\hline CCL19 & $\begin{array}{l}\text { Portal-associated } \\
\text { lymphoid tissue }[15]\end{array}$ & $\begin{array}{l}\text { T-cell and DC homing to secondary } \\
\text { lymphoid tissue and lymphoid development }\end{array}$ & $\begin{array}{l}\text { CCR7: naive T, B, mature } \\
\text { mDC, Th1, Th2, and Treg }\end{array}$ \\
\hline CCL20 & $\begin{array}{l}\text { Endothelial cells, } \\
\text { macrophages, and DC in the livers } \\
{[55]}\end{array}$ & $\begin{array}{l}\text { DC migration, memory T-cells, and Th17 cells } \\
\text { at site of inflammation }\end{array}$ & $\begin{array}{l}\text { CCR6: memory T cells, B cells, } \\
\text { Th17, and immature mDC }\end{array}$ \\
\hline CCL21 & $\begin{array}{l}\text { Portal-associated } \\
\text { lymphoid tissue [15] }\end{array}$ & $\begin{array}{l}\text { T-cell and DC homing to secondary } \\
\text { lymphoid tissue; lymphoid development; } \\
\text { T-cell recruitment; adaptive immunity; and } \\
\text { Th1, Th2, Th17, and Treg inflammation }\end{array}$ & $\begin{array}{l}\text { CXCR3 (mouse): memory T } \\
\text { cells, Th1, Th2, Th17, Treg, and } \\
\text { NKT } \\
\text { CCR7: naive T, B, mature } \\
\text { mDC, Th1, Th2, and Treg }\end{array}$ \\
\hline CCL22 & $\begin{array}{l}\text { DC, B cell, and macrophages } \\
\text { (Kupffer cells) [56] }\end{array}$ & $\begin{array}{l}\text { T-cell and monocyte migration, allergic } \\
\text { inflammation, Treg retention, and T-cell skin } \\
\text { homing }\end{array}$ & $\begin{array}{l}\text { CCR4: Th2 cells, Treg } \\
\text { eosinophils, basophils, DC, } \\
\text { and Treg }\end{array}$ \\
\hline CCL23 & Macrophages (Kupffer cells) [57] & $\begin{array}{l}\text { Chemotactic activity on resting } \mathrm{T} \text { cell, } \\
\text { monocytes, and neutrophils }\end{array}$ & $\begin{array}{l}\text { CCR1: monocytes, memory } \mathrm{T} \\
\text { cells, Th1, and NK }\end{array}$ \\
\hline CCL24 & Lower levels in the liver [58] & $\begin{array}{l}\text { Eosinophil and basophil migration, allergic } \\
\text { inflammation, and Th2 response }\end{array}$ & $\begin{array}{l}\text { CCR3: eosinophils and } \\
\text { basophils }\end{array}$ \\
\hline CCL25 & $\begin{array}{l}\text { macrophages, Kupffer cells, DC, } \\
\text { and cholangiocytes [59] }\end{array}$ & $\begin{array}{l}\text { Recruitment of adaptive immune cells to the } \\
\text { liver. T-cell homing to gut and thymus and } \\
\text { tolerogenic DC }\end{array}$ & $\begin{array}{l}\text { CCR9: DC, memory T cells, } \\
\text { and thymocytes }\end{array}$ \\
\hline CCL26 & Vascular endothelial cells [60] & $\begin{array}{l}\text { Eosinophil and basophil migration, allergic } \\
\text { inflammation, and Th2 response }\end{array}$ & $\begin{array}{l}\text { CCR3: eosinophils and } \\
\text { basophils }\end{array}$ \\
\hline CCL27 & $\begin{array}{l}\text { No expression in liver and } \\
\text { predominantly in the skin } \\
\text { keratinocytes [61] }\end{array}$ & T-cell trafficking in the skin & $\begin{array}{l}\text { CCR10: memory T cells and } \\
\text { Treg }\end{array}$ \\
\hline
\end{tabular}


TABLE 2: Continued.

\begin{tabular}{|c|c|c|c|}
\hline Chemokine & Location in the liver & Function & $\begin{array}{l}\text { Receptors and their } \\
\text { distribution }\end{array}$ \\
\hline CCL28 & $\begin{array}{l}\text { Biliary epithelium } \\
\text { (cholangiocytes) [15] }\end{array}$ & T-cell homing to skin and bowel & $\begin{array}{l}\text { CCR10: memory T cells and } \\
\text { Treg }\end{array}$ \\
\hline \multicolumn{4}{|l|}{ C subfamily } \\
\hline XCL1 & Not expressed in human liver [62] & NK-cell recruitment & XCR1: NK \\
\hline XCL2 & Preferentially in CD8+ T cells [63] & NK-cell recruitment & XCR1: NK \\
\hline \multicolumn{4}{|c|}{ CX3C subfamily } \\
\hline CX3CL1 & Biliary epithelium [64] & $\begin{array}{l}\text { Th1 inflammation, T-cell, NK cell trafficking } \\
\text { and adhesion, and innate and adaptive } \\
\text { immunity }\end{array}$ & $\begin{array}{l}\text { CX3CR1: monocytes, and Th1, } \\
\text { NK }\end{array}$ \\
\hline
\end{tabular}

CXCL: C-X-C motif chemokine ligand; CXCR: C-X-C motif chemokine receptor; CCL: C-C motif chemokine ligand; CCR: C-C motif chemokine receptor; XCL: X-C motif chemokine ligand; XCR: X-C motif chemokine receptor; CX3CL: C-X3-C motif chemokine ligand; CX3CR: C-X3-C motif chemokine receptor; Th1: T helper 1; Th2: T helper 2; Th17: T helper 17; Treg: regulatory T cell; NK: natural killer; NKT: natural killer T; DC: dendritic cell; pDC: plasmacytoid dendritic cell; mDC: myeloid dendritic cell; PMN: polymorphs.

fourth ones, has recently been reported in Zebrafish [68], but there is no evidence that this kind of chemokine exists in mammals.

According to the subfamily of their major ligands, the chemokine receptors are also classified into four subfamilies [17]. They are generally a kind of 7-transmembrane-spanning $\mathrm{G}$ proteins, which are composed of $\alpha, \beta$, and $\gamma$ subunits. The chemokine can activate downstream signal transduction events following the interaction with its receptor (leading to the exchanging of GTP for GDP between different subunits of the receptor and dissociation of the $\alpha$ subunit from the $\beta$ and $\gamma$ subunit) [69]. The chemokines tend to have multiple chemokine receptors and some receptors also have large numbers of chemokine ligands [70]. The subfamily members of chemokines involved in the pathogenesis of liver disease are summarized in Table 2.

\section{The CXC Chemokine Family}

3.1. The CXC Chemokines and Early Liver Allograft Dysfunction. ELR containing $\left(\mathrm{ELR}^{+}\right) \mathrm{CXC}$ chemokines, known as chemoattractants for neutrophils [71, 72], are distinct from other CXC chemotactic cytokines by the presence of the sequence glutamic acid-leucine-arginine (ELR) near the amino terminal. And the majority of ELR ${ }^{+} \mathrm{CXC}$ chemokines bind to CXC chemokine receptor 2 (CXCR2) [73]. Significant timedependent upregulation of CXCL1 was identified in the braindead donor livers [74]. However, these local inflammatory responses can lead to primary allograft dysfunction [75] after organ transplant from a brain-dead donor. CXCL2, known as macrophage inflammatory protein (MIP)-2, has been identified to stimulate tumor cell migration in vitro and angiogenesis and tumor growth in vivo [76]. Nevertheless, elevated levels of CXCL2 in graft livers have also been associated with ischemia/reperfusion injury after liver transplantation [77]. CXCL2 and its receptors are important mediators involved in neutrophil-dependent hepatic injury induced by ischemia and reperfusion [78]. Additionally, the pulmonary injury after liver transplantation was identified in mice and humans. Further studies have suggested that cold ischemia time prolongation upregulates pulmonary CXCL2 expression via hepatic-derived tumor necrosis factor- $\alpha$ (TNF- $\alpha$ ) and promotes neutrophils accumulation resulting in increased pulmonary injury after liver transplantation [79]. CXCL8 promotes rapid liver regeneration after drug-induced acute injury and may have tremendous clinical potential in reducing the need for liver transplantation and the mortality associated with acetaminophen-induced fulminant liver failure [80]. Collectively, these studies suggest that $\mathrm{ELR}^{+} \mathrm{CXC}$ chemokines and their receptors, axis may play an important role in neutrophil recruitment and mediate early allograft injury, which is a known risk factor for the pathogenesis and development of chronic liver allograft dysfunction.

ELR $^{-}$CXC chemokines include CXCL9, CXCL10, CXCL11, CXCL12, CXCL13, and CXCL14. Their receptors, including CXCR3, CXCR4, CXCR5, and CXCR7, are expressed predominantly on Th1 cells, Th2 cells, Th17 cells, Treg cells, memory T cells, some B cells, and natural killer cells [81]. The serum levels of CXCL9 and CXCL10 measured by Luminex multiplex assays increased in recipients with early allograft dysfunction after liver transplantation and correlated with T-cell recruitment [4]. Increased expression of CXCR3, CXCR4, and CCR5 has been shown on circulating and graftinfiltrating lymphocytes after liver transplantation [82]. These studies suggest that $\mathrm{ELR}^{-} \mathrm{CXC}$ chemokines participate in lymphocyte recruitment in virtually all stages after transplantation and are involved in the retention of alloactivated lymphocytes at sites of graft damage, correlating with the pathogenesis early liver allograft dysfunction.

3.2. The CXC Chemokines and Acute Rejection after Liver Transplantation. Several experimental and clinical studies have implicated the ELR ${ }^{-}$CXC chemokines/CXCR3 axis in reference to acute cellular rejection. Interestingly, full MHCmismatched donor hearts had prolonged survival in $\mathrm{CXCR}^{-/-}$mice [83]. The similar results have been yielded when blocking antibodies to CXCR3 was used for heart allograft transplantation [84].

In vivo treatment with interferon- $\gamma($ IFN- $\gamma)$ upregulates both hepatocyte and nonparenchymal cell (i.e., monocytes/ 
macrophages, neutrophils, and other inflammatory cells) expression of CXCL9 $[33,85]$. CXCL9 is strongly expressed on vascular and sinusoidal endothelium in rejecting hepatic allografts [82]. The interaction between CXCL9 and its receptor CXCR3 is important in recruiting lymphocytes to sites of inflammation within liver tissue [14]. The significant increasing expression of CXCL10, and CXCL11 and their receptor CXCR3 [86], together with the increase of B lymphocytes and plasma cells in liver biopsy specimens from patients with acute allograft rejection, indicates that the migration of $\mathrm{B}$ lymphocytes and plasma cellspromoted by the expression of chemokines/receptors, plays a key role in acute liver rejection [87]. Additionally, the chemokine CXCL11/CXCR3 axis has an important role in the homing of CD4(+) T cells [88] and NK cells [86] in acute rejection models of solid organ transplantation. However, when compared with the biological responses induced by CXCL9 or CXCL10, CXCL11 is of higher potency and efficacy in activated $\mathrm{T}$ cells and cells transfected with CXCR3 [14].

Collectively, the expression of CXCL9 and of other CXCR3 ligands (i.e., CXCL10 and CXCL11) is induced in rejecting hepatic allografts [82], with the increased expression of CXCR3 [89] on circulating and hepatic lymphocytes, suggesting that these chemokines may be therapeutic targets for acute liver allograft rejection.

3.3. The CXC Chemokines and Hepatic Ischemia Reperfusion $(I / R)$ Injury. Hepatic ischemia reperfusion $(I / R)$ injury is an important clinical problem after liver resection or transplantation [90]. It can be categorized into warm I/R and cold storage reperfusion injury [91]. Furthermore, hepatic warm I/R injury can be subdivided into two distinct phases [92]. The initial phase ( $<2 \mathrm{~h}$ after reperfusion) is characterized by Kupffer cells (KC) mediated responses and oxidant stress, which results in the release of TNF- $\alpha$ [93]; the late phase of injury (from 6 to $48 \mathrm{~h}$ after reperfusion) is characterized by neutrophil accumulation and CXC chemokine production, which results in hepatocellular injury $[94,95]$.

Specifically, the last studies have suggested that liver sinusoidal endothelial cells (LSEC) damage, which occurs during cold preservation, represents the initial factor leading to liver I/R injury [90]. KC and LSEC edema, together with the imbalance between low nitric oxide (NO) bioavailability and exacerbated thromboxane A2 (TXA2) and endothelin (ET) production, contributes to liver microcirculatory dysfunction. KC activation is promoted by increased production of damage-associated molecular patterns (DAMPs) and pathogen-associated molecular patterns (PAMPs) by neighbouring hepatic cells [91]. Then activated KC significantly increase their release of ROS and proinflammatory cytokines including TNF- $\alpha$, interleukin-1 (IL-1), IFN- $\gamma$, and interleukin-12 (IL-12) [92], which induces the expression of P-selectin, intracellular adhesion molecule-1 (ICAM-1), integrins, IL-6, IL-8 in LSEC, and overexpression of ELR containing CXC chemokines (i.e., CXC-1,-2,-3,-5, and -8) with their receptors CXCR1 and CXCR2 being expressed on neutrophils, SECs, and hepatocytes [96]. Additionally, IL-1 and TNF- $\alpha$ recruit and activate CD4+T-lymphocytes, which amplify KC activation and promote neutrophil recruitment and adherence into the liver sinusoids [97]. The inflammatory pathways of hepatic ischemia/reperfusion (I/R) injury are shown in Figure 1.

However, CXC chemokines regulate both the injury and recovery from I/R after liver surgery [7]. Ren and his colleagues have firstly reported that $\mathrm{ELR}^{+} \mathrm{CXC}$ chemokines were shown to induce proliferation in hepatocytes in animal models [98]. These findings have also been identified in liver regeneration following 70\% partial hepatectomy. When ELR chemokines were neutralized using antibodies, liver regeneration was impaired in the mass of remnant liver; conversely, hepatocyte proliferation and liver regeneration were accelerated by treatment of mice with CXCL2 after partial hepatectomy [98]. Additionally, pharmacological antagonism or genetic deletion of CXCR2 after hepatic I/R resulted in augmented hepatocyte proliferation and accelerated recovery from injury [99]. The chemokine receptor CXCR1 shares ligands with CXCR2. However, hepatocyte proliferation was decreased in $\mathrm{CXCR}^{-/-}$mice in vivo [100]. This study suggested that CXCR1 appears to facilitate repair and regenerative responses after I/R injury. CXC chemokines and their receptors have significant impact on potential therapeutic modulation of hepatic I/R injury.

\section{The CC Chemokine Family}

4.1. The CC Chemokines and Early Liver Allograft Dysfunction. Early allograft dysfunction (EAD) among liver transplant recipients is characterized by early high transaminases, persistent cholestasis, and prolonged coagulopathy [101, 102]. EAD occurring in the first week after liver transplantation is associated with increased graft failure and mortality and is often thought to be secondary to ischemia/reperfusion (I/R) injury [4]. Several perioperative factors, such as hypotension, reperfusion, donor brain death, and cold storage, contribute to the pathogenesis and development of EAD. Secondary to oxidative stress, cell death, and the release of inflammatory mediators in $\mathrm{I} / \mathrm{R}$ injury, reactive oxygen intermediates are generated and the CC chemokines are released [103].

Twenty-eight CC chemokines have been characterized as up-to-date. And these CC chemokines were centrally involved in the activation or recruitment of T cells, NK cells, or $\mathrm{B}$ cells, depending on the biological context [104]. The expression of many CC chemokines in Kupffer cells is regulated by NF- $\kappa$ B pathway activation [105]. Additionally, many CC chemokines are recently identified to play important roles in the pathogenesis of liver diseases.

Serum levels of peripheral blood CC chemokines, such as CCL2, CCL3, CCL4, and CCL5, pre- and postoperatively in patients with or without EAD were measured by Luminex multiplex assays [4]. Then the correlations were found between preoperative and postoperative expression of several chemokines and the development of EAD following liver transplantation. Although these serum proteins were showing significant change associated with EAD, it is not clear whether they represent the actual cause or effect of organ dys- 


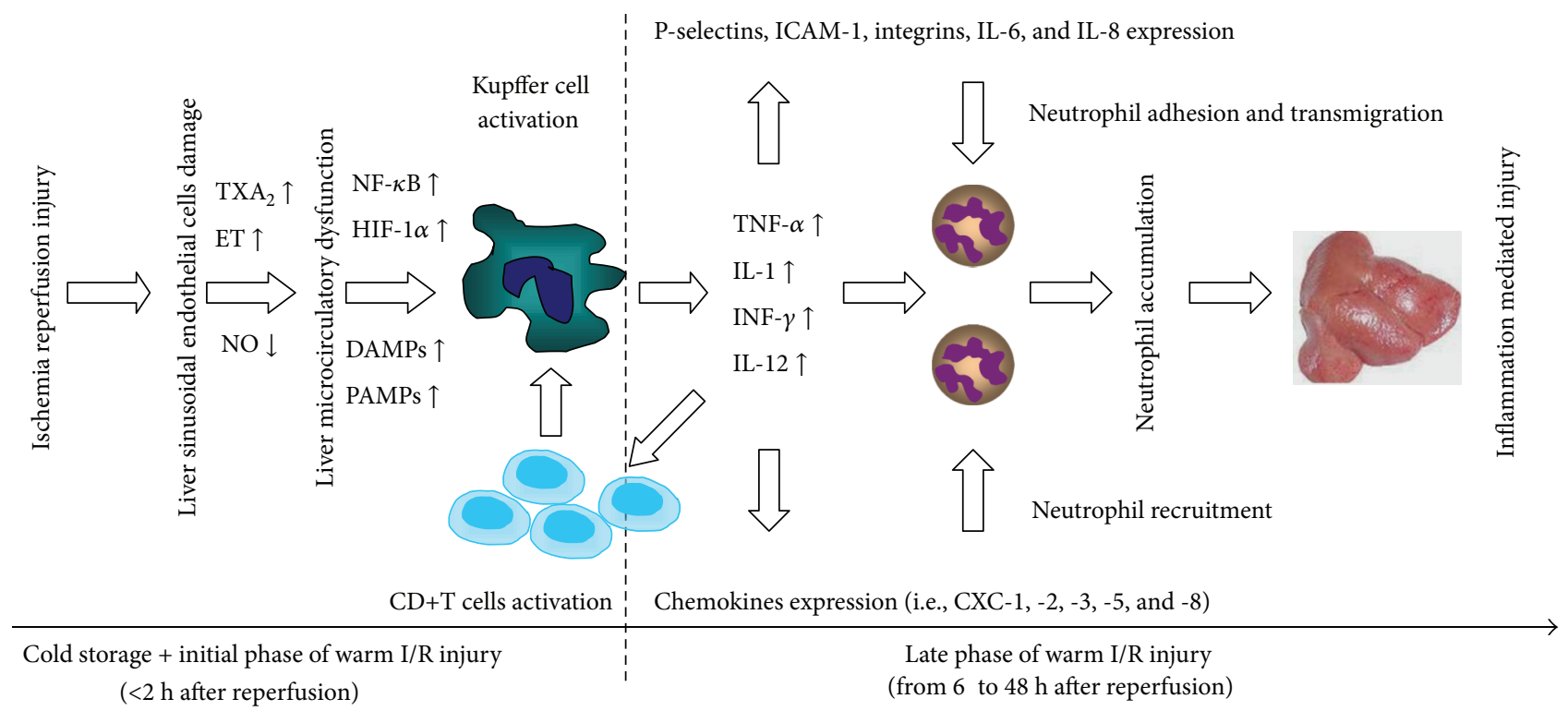

FIGURE 1: The inflammatory pathways of hepatic ischemia/reperfusion (I/R) injury. Liver sinusoidal endothelial cells (LSEC) damage, which occurs during cold preservation, represents the initial factor leading to liver I/R injury. Kupffer cell (KC) and LSEC edema, together with the imbalance between nitric oxide (NO) $(\downarrow)$ and thromboxane A2 (TXA2) ( $\uparrow$ ) and endothelin (ET) ( $\uparrow$ ), contributes to liver microcirculatory dysfunction. KC activation is promoted by damage-associated molecular patterns (DAMPs) $(\uparrow)$ and pathogen-associated molecular patterns (PAMPs) $(\uparrow$ ) produced by neighbouring hepatic cells. Then activated KCs increase their release of ROS and proinflammatory cytokines including tumour necrosis factor-a (TNF-a), interleukin-1 (IL-1), interferon- (INF), interleukin-12 (IL-12), which induces the expression of P-selectin, intracellular adhesion molecule-1 (ICAM-1), integrins, IL-6, IL-8 in LSEC and the release of chemokines (i.e., CXC-1,-2,-3,-5, and -8). Additionally, IL-1 and TNF-a recruit and activate CD4+ T-lymphocytes, which amplify KC activation and promote neutrophil recruitment and adherence into the liver sinusoids and finally execute liver inflammation and injury.

function or part of a new pathogenic process altogether. Further studies should be required to validate that these serum levels of peripheral blood CC chemokines are indeed part of a pathophysiologic mechanism with EAD.

\subsection{The CC Chemokines and Acute Rejection after Liver Trans-} plantation. Acute liver allograft rejection is characterized by a mixed portal tract infiltrate that contains mononuclear cells in human or rat liver transplant allografts $(\mathrm{DA} \rightarrow$ Lewis orthotopic liver transplantation model). The accumulation of activated lymphocytes into the allograft plays an important role in the pathogenesis of tissue injury. Chemokines recruit the lymphocytes from the circulation and promote the migration, positioning, and retention of effector cells in the graft [82]. These chemotactic factors are expressed and secreted by a wide variety of cell types including lymphocytes [106] and endothelial components of rejecting allografts [107] in response to activation [108]. Several studies have shown that CCL2 (monocyte chemoattractant protein-1), CCL3 (macrophage inflammatory protein-1 $\alpha$ ), CCL3L1 [109], and CCL5 (RANTES) are upregulated in rejecting liver allografts [110]. Within the liver graft, chemokine-producing endothelial cells (CCL3, CCL4, and CCL5) and biliary epithelial cells (CCL2 and CXCL8) contribute to inflammation during transplant rejection $[108,111]$. Specifically, CCL3 is upregulated in allografts as early as $6 \mathrm{~h}$ after transplantation.
The early expression of CCL3 in liver allografts leads to increased intragraft inflammation by attracting recipientderived NK cells [86] before T-cell infiltration [112]. It has been proven that graft-infiltrating NK cells are a major source of IFN- $\gamma$, which is an important immunoregulatory cytokine during early posttransplant period. The serum IFN- $\gamma$ levels were markedly increased by day three after transplanation in recipients [86]. IFN- $\gamma$-producing NK cells are an important link between the innate and adaptive immune responses early after liver transplantation. So CC chemokines, NK cells, and innate immunity may be important in the early events leading to allograft rejection.

The C4d deposits along the portal capillaries in liver allografts indicate a humorally mediated immunoresponse caused by the accumulated B and plasma cells. During acute rejection, a significant increase of $\mathrm{B}$ lymphocytes and plasma cells, together with CCL20 (macrophage inflammatory protein-3alpha) and its receptor CCR-6, was detected in the portal fields of all biopsy specimens [87]. This result indicates that the migration of $\mathrm{B}$ lymphocytes and plasma cells promoted by the expression of B-cell activating chemokines/receptors plays a key role in acute liver rejection.

Chemokine receptors CCR2 and CCR5 are also found being upregulated on infiltrating lymphocytes and Kupffer cells during acute and chronic rejection [82]. Genes for the CC chemokine receptors CCR2 and CCR5 are characterized by polymorphisms which are associated with significant 
alterations in their function [113]. Fischereder study group reported that the homozygous expression of chemokine polymorphisms CCR5-delta 32 was associated with a significantly improved survival of renal transplant allografts [114]. However, genotyped DNA PCR or PCR-RFLP analysis in 207 liver transplant recipients suggested that the gene frequency of the CCR2-641, and CCR5-delta 32 alleles had no significant difference in recipients [115]. It was suggested that the CCR2641 and CCR5-delta 32 polymorphisms did not influence the risk for acute rejection of liver allografts or graft survival $[115,116]$.

4.3. The CC Chemokines and Ischemic-Type Biliary Lesions. There is no doubt that the bile ducts are the Achilles' heel of the liver graft. Thus, ischemic-type biliary lesions (ITBL) are a life-threatening complication following liver transplantation [117], with an incidence varying between 5\% and 26\% $[118,119]$. The prevalence of ITBL continues to increase with time after liver transplantation $[120,121]$. ITBL is a radiological diagnosis, characterized by intra- and/or extrahepatic strictures and dilatations on a cholangiogram after orthotopic liver transplantation without any known cause. According to the features of ITBL (including bile duct stenoses, dilatations, and cast formation) and the therapeutic consequences, two major types can be distinguished: type A (the complete biliary system is affected) and type B (only the major extrahepatic bile ducts are involved). The pathological features of ITBL observed in liver allografts include the epithelial and muscular necrosis of the biliary system with periductal connective tissue being remarkably well preserved [27].

The underlying cause of ITBL remains unclear despite numerous studies [122]. Identified causes include ischemiarelated injury, immunologically induced injury, and cytotoxic injury induced by bile salts. However, the etiology of ITBL appeared to be mostly related to ischemic injury [123]. Immunological injury is associated with $\mathrm{ABO}$ incompatibility, polymorphism in genes coding for chemokines, and pre-existing immunologically mediated diseases [118].

Chemokines CCL2 (monocyte chemotactic protein-1) is produced and secreted from cholangiocytes under pathological conditions [124]. It could result in the recruitment and activation of $\mathrm{T}$ cells, macrophages, and natural killer cells to protect against biliary infection [125]. CC chemokine receptor 5 (CCR5) and its ligands (CCL3 and CCL4) play a key role in postischemic and inflammatory damage [126]. CCR5 deta32 polymorphism is a mutant allele of CCR5 with an internal deletion of 32 base pair (bp). It has been shown to lead to a lower rate of acute rejection and improved survival after kidney transplantation [127]. For detecting CCR5-delta 32 polymorphism in blood samples of patients after liver transplantation, CCR5 polymerase chain reaction (PCR) analysis was performed in 146 recipients. Finally, 120 patients with wild-type CCR5 and 26 patients with CCR5-delta 32 were identified in this study. And ITBL occurred in 14 of 120 patients with wild-type CCR5 and in 8 of 26 patients with CCR5-delta 32 polymorphism. Compared to kidney transplantation, however, this study has suggested that CCR5-delta 32 is a significant risk factor for the development of ITBL after liver transplantation and leads to a reduction in grafts and recipient's survival [128].

\section{The C Chemokine Family}

The $\mathrm{C}$ chemokine family includes XCL1 and XCL2 in humans, both of which bind the XCR1 receptor. XCL1, also named lymphotactin, activation-induced T-cell-derived and chemokine-related molecule (ATAC), and single C motif-1 (SCM-1), have just two cysteine residues, only one of which is located at the N-terminus. XCL2 (also called SCM-1a) is different from XCL1 by only two N-terminal amino acids. XCL1 is released from T cells, NK cells, NKT cells, $\gamma / \delta$ T cells, mast cells, and medullary thymic epithelial cells (mTECs) during infectious and inflammatory responses $[14,129]$, whereas XCR1 is expressed by a dendritic cell (DC) subpopulation (i.e., murine CD8+ DC and human CD141+ DC) [130] and is correlated with the ability of DCs to cross-present antigen [131].

XCL1 is essential for the medullary accumulation of thymic dendritic cell (tDCs) [132]. Naturally occurring regulatory $\mathrm{T}$ cells (nT reg cell) development is impaired in the thymus of Xcl1-deficient mice; thymocytes generated in Xcl1deficient mice are potent in triggering and fail to establish self-tolerance [132]. Flow cytometry and PCR analysis showed a reduction in XCL1 and XCR1 expression, which was associated with the suboptimal regulatory function of Treg. Interestingly, Treg-mediated suppression and cytotoxicity in allergic asthma significantly increased when expression of XCL1 was upregulated [133]. So XCL1 and XCR1 are constitutively expressed in the thymus and regulate the thymic establishment of self-tolerance. Although XCL1 and XCR1 mRNA were not expressed in human liver tissue when analysed by the northern blot [62], disordered hepatocytes taken up by XCR1+ DCs will be digested and processed and hepatocellular antigens will be cross-presented by the MHC-class I molecules to CD8+ T cells [131]. Thus, the special ability of $\mathrm{XCR} 1+$ DCs contributes to self-tolerance in the innate and adaptive immune responses.

The XCL1-XCR1 axis plays an important role in DC-mediated cytotoxic immune response and critically contributes to the generation of thymic self-tolerance and development of regulatory $\mathrm{T}$ (Treg) cells [129]. Interestingly, considering restricted expression by human CD141+ DCs, XCR1 emerges as a prime candidate for vaccines designed to induce selective cytotoxic immunity.

\section{The $\mathrm{CX}_{3} \mathrm{C}$ Chemokine Family}

The chemokine $\mathrm{CX}_{3} \mathrm{CL1}$, also known as fractalkine, is the only member of the $\mathrm{CX}_{3} \mathrm{C}$ chemokine family. The two N-terminal cysteine molecules are separated by three different amino acids in $\mathrm{CX}_{3} \mathrm{CL1}$ domain. $\mathrm{CX}_{3} \mathrm{CL1}$, synthesized as a transmembrane protein with an extended mucin-like stalk on which a chemokine domain is located, is induced in activated primary endothelial cells. This CX3C chemokine can promote strong adhesion of $\mathrm{T}$ cells and monocytes [64].

$\mathrm{CX}_{3} \mathrm{CR} 1\left(\mathrm{C}-\mathrm{X}_{3}-\mathrm{C}\right.$ motif receptor 1$)$ is the only one known receptor corresponding to this chemokine. It is primarily 
expressed on circulating monocytes, tissue macrophages, tissue DC (dendritic cell), and T-cell and natural killer (NK) cell populations [134]. Recent studies have shown $\mathrm{CX}_{3} \mathrm{CL1}$ in the pathogenesis of brain [135] and cardiac [136] disorders. However, $\mathrm{CX}_{3}$ CL1mRNA was constitutively expressed in Kupffer cells and hepatocytes, especially the hepatocytes around the central veins [14]. And $\mathrm{CX}_{3} \mathrm{CR} 1$ expression has been identified on the biliary epithelium, hepatic stellate cells (HSCs), and hepatoma cell lines in the liver [137].

Serum concentrations of $\mathrm{CX}_{3} \mathrm{CL} 1$ and its specific receptor $\mathrm{CX}_{3} \mathrm{CR} 1$ were significantly elevated [138] in patients with chronic liver diseases at different stages of fibrosis progression. And a correlation was observed between serum $\mathrm{CX}_{3} \mathrm{CL} 1$ and quantitative serum fibrosis markers (i.e., hyaluronan or procollagen III peptide) in the patients [139]. However, realtime qPCR analysis showed a reduction in cx3cll and cx $3 \mathrm{crl}$ intrahepatic expression in patients with different stages of liver fibrosis versus nonfibrotic livers [139]. Further studies have indicated that human HSCs downregulate $\mathrm{CX}_{3} \mathrm{CR} 1$ surface expression ex vivo [140] and that the number of activated HSCs may influence $\mathrm{CX}_{3}$ CL1 serum levels [139].

$\mathrm{CX}_{3} \mathrm{CR} 1$ in the damaged liver promotes the survival of infiltrating monocytes and guides the differentiation of monocyte derived macrophages [44]. So more intrahepatic inflammatory cells and intrahepatic macrophage accumulation were observed in $\mathrm{CX}_{3} \mathrm{CR}^{-/-}$liver. And $\mathrm{CX}_{3} \mathrm{CR}^{-/-}$mice strikingly developed more progressive fibrosis than wild-type (WT) animals [139]. By activating anti-inflammatory signals in hepatic macrophages, the $\mathrm{CX}_{3} \mathrm{CL1}-\mathrm{CX}_{3} \mathrm{CR} 1$ axis plays a protective function that limits liver inflammation and fibrosis in vivo [140]. These preliminary studies have thoroughly indicated that $\mathrm{CX}_{3} \mathrm{CL1}-\mathrm{CX}_{3} \mathrm{CR} 1$ axis plays an important role in the pathogenesis and development of chronic liver allograft dysfunction. So pharmacological augmentation of fractalkine- $\mathrm{CX}_{3} \mathrm{CR} 1$ pathway may represent a potential therapeutic agent in liver diseases.

\section{Experimentally Therapeutic Applications of Chemokines and Their Receptors}

The chemokines and their receptors axis represents a potential pharmacologic target for various human diseases. Especially, by recruiting and activating polymorphonuclear (PMN) cells and T cells into allografts during the progression of I/R injury, CXCL8 and its CXCR1/CXCR2 receptors contribute to the physiopathology of acute rejection [141] and increase the incidence of primary nonfunction, primary graft dysfunction, and biliary structures after liver transplantation. So present studies on therapeutic uses of chemokine receptor antagonists and blocking antibodies are emerging in the literatures. Generally, these recombinated/engineered smallmolecule chemokine inhibitors can be divided into four types: antichemokine antibodies (mAb), chemokine antagonist, DNA plasmid encoding chemokine compounds, and chimerical chemokine compounds (or N-terminal modified chemokines) $[142,143]$. Mainstream attention has been devoted to the development of $\mathrm{ELR}^{+} \mathrm{CXC}$ chemokines receptor antagonists and blocking antibodies.
CXCR1 and CXCR2 are the two major chemokine receptors expressed on the surface of PMNs, endothelial cells and $\mathrm{T}$ cells in immune responses. Several classes of CXCR1 and CXCR2 antagonists have been reported in the literature. Reparixin (known as repertaxin) and DF 2156A are described as noncompetitive allosteric inhibitors of CXCL8 receptors CXCR1 and CXCR2 with optimal pharmacokinetic profiles. In rat model of liver $\mathrm{I} / \mathrm{R}$ injury, they drastically inhibited $\mathrm{PMN}$ and monocyte/macrophage recruitment into reperfused livers and reduced liver damage in terms of alanineaminotransferase levels and hepatocellular necrosis [141]. The experimental data, along with those showing a reduced reperfusion injury by anti-CXCL1, anti-CXCR2 antibodies, and CXCL8 receptor inhibitors $[144,145]$, clearly demonstrated the therapeutic potential of these $\mathrm{ELR}^{+} \mathrm{CXC}$ chemokines receptors antagonists and blocking antibodies in the prevention of I/R injury and acute rejection in organ transplantation.

\section{Summary}

Despite the discoveries in chemokine biology that have led to important advances in our understanding of immune responses, angiogenesis, carcinogenesis, and cell cycle control over the last 25 years, the role of chemokines in chronic liver allograft dysfunction remains unanswered. The complex interactions between the chemokine superfamily and other cellular contributors shown in several studies are only just beginning to be mapped. Moreover, an understanding of the biological roles that chemokines play in the pathogenesis of chronic liver allograft dysfunction lags behind that for other conditions such as circulatory, respiratory, or haematological disorders. It is necessary for us to understand the chemokine superfamily and its functions in the organism from a perspective concerning chronic liver allograft dysfunction. Only by understanding the interaction of chemokines and their receptors will it be possible to design therapeutic strategies and pharmaceutical agents to ameliorate chronic liver allograft dysfunction and ultimately enhance long-term recipient and allograft survival after liver transplantation.

\section{Conflict of Interests}

The authors state that there is no conflict of interests related to this paper.

\section{Acknowledgments}

This work was supported by grants from National Natural Science Foundation of China (Grant no. 81170453), Beijing, China; National Natural Science Foundation of China (Grant no. 81301025), Beijing, China; Tianjin City High School Science and Technology Fund Planning Project (Grant no. 20120118), Tianjin, China; and Foundation of Tianjin Medical University (Grant no. 2009ky20), Tianjin, China. 


\section{References}

[1] J. Yang, M. Q. Xu, L. N. Yan, X. B. Chen, and J. Liu, “Zinc finger protein $\mathrm{A} 20$ protects rats against chronic liver allograft dysfunction," World Journal of Gastroenterology, vol. 18, no. 27, pp. 3537-3550, 2012.

[2] O. Pappo, H. Ramos, T. E. Starzl, J. J. Fung, and A. J. Demetris, "Structural integrity and identification of causes of liver allograft dysfunction occurring more than 5 years after transplantation," American Journal of Surgical Pathology, vol. 19, no. 2, pp. 192-206, 1995.

[3] J. Neuberger, "Chronic allograft dysfunction: diagnosis and management. Is it always progressive?" Liver Transplantation, vol. 11, no. 11, supplement 2, pp. S63-S68, 2005.

[4] B. H. Friedman, J. H. Wolf, L. Wang et al., "Serum cytokine profiles associated with early allograft dysfunction in patients undergoing liver transplantation," Liver Transplantation, vol. 18, no. 2, pp. 166-176, 2012.

[5] U. Khettry, A. Backer, G. Ayata, W. D. Lewis, R. L. Jenkins, and F. D. Gordon, "Centrilobular histopathologic changes in liver transplant biopsies," Human Pathology, vol. 33, no. 3, pp. 270276, 2002.

[6] B. Liu, L.-N. Yan, W.-T. Wang et al., "Clinical study on safety of adult-to-adult living donor liver transplantation in both donors and recipients," World Journal of Gastroenterology, vol. 13, no. 6, pp. 955-959, 2007.

[7] E. Gane, B. Portmann, R. Saxena, P. Wong, J. Ramage, and R. Williams, "Nodular regenerative hyperplasia of the liver graft after liver transplantation," Hepatology, vol. 20, no. 1, pp. 88-94, 1994.

[8] A. J. Czaja, "Autoimmune hepatitis after liver transplantation and other lessons of self-intolerance," Liver Transplantation, vol. 8, no. 6, pp. 505-513, 2002.

[9] J. Li, B. Liu, L.-N. Yan et al., "Microproteinuria for detecting calcineurin inhibitor-related nephrotoxicity after liver transplantation," World Journal of Gastroenterology, vol. 15, no. 23, pp. 29132917, 2009.

[10] P.-A. Clavien, P. R. C. Harvey, and S. M. Strasberg, "Preservation and reperfusion injuries in liver allografts: an overview and synthesis of current studies," Transplantation, vol. 53, no. 5, pp. 957-978, 1992.

[11] P. McMaster, B. Herbertson, C. Cusick, R. Y. Calne, and R. Williams, "Biliary sludging following liver transplantation in man," Transplantation, vol. 25, no. 2, pp. 56-62, 1978.

[12] B. Liu, L.-N. Yan, J. Li et al., "Using the clavien grading system to classify the complications of right hepatectomy in living donors," Transplantation Proceedings, vol. 41, no. 5, pp. 1703-1706, 2009.

[13] W. R. Kim, J. J. Poterucha, M. K. Porayko, E. R. Dickson, J. L. Steers, and R. H. Wiesner, "Recurrence of nonalcoholic steatohepatitis following liver transplantation," Transplantation, vol. 62, no. 12, pp. 1802-1805, 1996.

[14] K. J. Simpson, N. C. Henderson, C. L. Bone-Larson, N. W. Lukacs, C. M. Hogaboam, and S. L. Kunkel, "Chemokines in the pathogenesis of liver disease: so many players with poorly defined roles," Clinical Science, vol. 104, no. 1, pp. 47-63, 2003.

[15] Y. H. Oo, S. Shetty, and D. H. Adams, "The role of chemokines in the recruitment of lymphocytes to the liver," Digestive Diseases, vol. 28, no. 1, pp. 31-44, 2010.

[16] M. Melter, G. McMahon, J. Fang, P. Ganz, and D. Briscoe, "Current understanding of chemokine involvement in allograft transplantation," Pediatric Transplantation, vol. 3, no. 1, pp. 1021, 1999.

[17] A. Zlotnik, O. Yoshie, and H. Nomiyama, "The chemokine and chemokine receptor superfamilies and their molecular evolution," Genome Biology, vol. 7, no. 12, article 243, 2006.

[18] R. Guerreiro, Q. Santos-Costa, and J. M. Azevedo-Pereira, "The chemokines and their receptors: characteristics and physiological functions," Acta Médica Portuguesa, vol. 24, no. 4, supplement, pp. 967-976, 2011.

[19] F. Sallusto and M. Baggiolini, "Chemokines and leukocyte traffic," Nature Immunology, vol. 9, no. 9, pp. 949-952, 2008.

[20] A. Zlotnik and O. Yoshie, "The chemokine superfamily revisited," Immunity, vol. 36, no. 5, pp. 705-716, 2012.

[21] H. E. Wasmuth and R. Weiskirchen, "Pathogenesis of liver fibrosis: modulation of stellate cells by chemokines," Zeitschrift fur Gastroenterologie, vol. 48, no. 1, pp. 38-45, 2010.

[22] A. J. Demetris, "Liver biopsy interpretation for causes of late liver allograft dysfunction," Hepatology, vol. 44, no. 2, pp. 489501, 2006.

[23] G. Mieli-Vergani and D. Vergani, "De novo autoimmune hepatitis after liver transplantation," Journal of Hepatology, vol. 40, no. 1, pp. 3-7, 2004.

[24] N. Kerkar, N. Hadzić, E. T. Davies et al., "De-novo autoimmune hepatitis after liver transplantation," The Lancet, vol. 351, no. 9100, pp. 409-413, 1998.

[25] A. Inui, T. Sogo, H. Komatsu, H. Miyakawa, and T. Fujisawa, "Antibodies against cytokeratin 8/18 in a patient with de novo autoimmune hepatitis after living-donor liver transplantation," Liver Transplantation, vol. 11, no. 5, pp. 504-507, 2005.

[26] M. Abu-Amara, S. Y. Yang, N. Tapuria, B. Fuller, B. Davidson, and A. Seifalian, "Liver ischemia/reperfusion injury: processes in inflammatory networks-a review," Liver Transplantation, vol. 16, no. 9, pp. 1016-1032, 2010.

[27] C. Moench, A. Uhrig, A. W. Lohse, and G. Otto, "CC chemokine receptor $5 \Delta 32$ polymorphism - a risk factor for ischemic-type biliary lesions following orthotopic liver transplantation," Liver Transplantation, vol. 10, no. 3, pp. 434-439, 2004.

[28] H. M. Evans, D. A. Kelly, P. J. McKiernan, and S. Hübscher, "Progressive histological damage in liver allografts following pediatric liver transplantation," Hepatology, vol. 43, no. 5, pp. 11091117, 2006.

[29] M. Sebagh, F. Yilmaz, V. Karam et al., "The histologic pattern of "biliary tract pathology" is accurate for the diagnosis of biliary complications," American Journal of Surgical Pathology, vol. 29, no. 3, pp. 318-323, 2005.

[30] S. G. Hubscher, E. Elias, J. A. C. Buckels, A. D. Mayer, P. McMaster, and J. M. Neuberger, "Primary biliary cirrhosis: histological evidence of disease recurrence after liver transplantation," Journal of Hepatology, vol. 18, no. 2, pp. 173-184, 1993.

[31] C. Rigamonti, M. Fraquelli, A. J. Bastiampillai et al., “Transient elastography identifies liver recipients with nonviral graft disease after transplantation: a guide for liver biopsy," Liver Transplantation, vol. 18 , no. 5, pp. 566-576, 2012.

[32] S. Friman, "Recurrence of disease after liver transplantation," Transplantation Proceedings Journal, vol. 45, no. 3, pp. 1178-1181, 2013.

[33] D. L. Rowell, L. Eckmann, M. B. Dwinell et al., "Human hepatocytes express an array of proinflammatory cytokines after agonist stimulation or bacterial invasion," American Journal of Physiology: Gastrointestinal and Liver Physiology, vol. 273, no. 2, pp. G322-G332, 1997. 
[34] K. Ohkubo, T. Masumoto, N. Horiike, and M. Onji, "Induction of CINC (interleukin-8) production in rat liver by non-parenchymal cells," Journal of Gastroenterology and Hepatology, vol. 13, no. 7, pp. 696-702, 1998.

[35] J. Liang, Y. Yamaguchi, F. Matsumura et al., "Calcium-channel blocker attenuates Kupffer cell production of cytokine- induced neutrophil chemoattractant following ischemia-reperfusion in rat liver," Digestive Diseases and Sciences, vol. 45, no. 1, pp. 201209, 2000.

[36] P. Romagnani, L. Maggi, B. Mazzinghi et al., "CXCR3-mediated opposite effects of CXCL10 and CXCL4 on TH1 or TH2 cytokine production," Journal of Allergy and Clinical Immunology, vol. 116, no. 6, pp. 1372-1379, 2005.

[37] S. Struyf, M. D. Burdick, P. Proost, J. Van Damme, and R. M. Stricter, "Platelets release CXCL4L1, a nonallelic variant of the chemokine platelet factor-4/CXCL4 and potent inhibitor of angiogenesis," Circulation Research, vol. 95, no. 9, pp. 855-857, 2004.

[38] K. Gijsbers, M. Gouwy, S. Struyf et al., "GCP-2/CXCL6 synergizes with other endothelial cell-derived chemokines in neutrophil mobilization and is associated with angiogenesis in gastrointestinal tumors," Experimental Cell Research, vol. 303, no. 2, pp. 331-342, 2005.

[39] E. Brandt, F. Petersen, A. Ludwig, J. E. Ehlert, L. Bock, and H.D. Flad, "The $\beta$-thromboglobulins and platelet factor 4: blood platelet-derived CXC chemokines with divergent roles in early neutrophil regulation," Journal of Leukocyte Biology, vol. 67, no. 4, pp. 471-478, 2000.

[40] P. L. Shields, C. M. Morland, M. Salmon, S. Qin, S. G. Hubscher, and D. H. Adams, "Chemokine and chemokine receptor interactions provide a mechanism for selective $\mathrm{T}$ cell recruitment to specific liver compartments within hepatitis C-infected liver," Journal of Immunology, vol. 163, no. 11, pp. 6236-6243, 1999.

[41] G. Lauletta, S. Russi, V. Conteduca, and L. Sansonno, "Hepatitis $\mathrm{C}$ virus infection and mixed cryoglobulinemia," Clinical and Developmental Immunology, vol. 2012, Article ID 502156, 11 pages, 2012.

[42] P.-A. Oldenborg, H. D. Gresham, and F. P. Lindberg, "CD47signal regulatory protein $\alpha(\operatorname{SIRP} \alpha)$ regulates $\mathrm{Fc} \gamma$ and complement receptor-mediated phagocytosis," Journal of Experimental Medicine, vol. 193, no. 7, pp. 855-861, 2001.

[43] X. Mu, Y. Chen, S. Wang, X. Huang, H. Pan, and M. Li, "Overexpression of VCC-1 gene in human hepatocellular carcinoma cells promotes cell proliferation and invasion," Acta Biochimica et Biophysica Sinica, vol. 41, no. 8, pp. 631-637, 2009.

[44] F. Tacke, "Functional role of intrahepatic monocyte subsets for the progression of liver inflammation and liver fibrosis in vivo," Fibrogenesis Tissue Repair, vol. 5, supplement 1, article S27, 2012.

[45] J. S. Serody, D. N. Cook, S. L. Kirby, E. Reap, T. C. Shea, and J. A. Frelinger, "Murine T lymphocytes incapable of producing macrophage inhibitory protein- $1 \alpha$ are impaired in causing graftversus-host disease across a class I but not class II major histocompatibility complex barrier," Blood, vol. 93, no. 1, pp. 43-50, 1999.

[46] D. H. Adams, S. Hubscher, J. Fear, J. Johnston, S. Shaw, and S. Afford, "Hepatic expression of macrophage inflammatory protein- $1 \alpha$ and macrophage inflammatory protein-1 $\beta$ after liver transplantation," Transplantation, vol. 61, no. 5, pp. 817-825, 1996.

[47] K. Tsuneyama, K. Harada, M. Yasoshima et al., "Monocyte chemotactic protein-1, -2 , and -3 are distinctively expressed in portal tracts and granulomata in primary biliary cirrhosis: implications for pathogenesis," The Journal of Pathology, vol. 193, no. 1, pp. 102-109, 2001.

[48] E. J. Quackenbush, V. Aguirre, B. K. Wershil, and J. C. GutierrezRamos, "Eotaxin influences the development of embryonic hematopoietic progenitors in the mouse," Journal of Leukocyte Biology, vol. 62, no. 5, pp. 661-666, 1997.

[49] K. M. Kopydlowski, C. A. Salkowski, M. J. Cody et al., "Regulation of macrophage chemokine expression by lipopolysaccharide in vitro and in vivo," Journal of Immunology, vol. 163, no. 3, pp. 1537-1544, 1999.

[50] E. Mendez-Enriquez and E. A. García-Zepeda, "The multiple faces of CCL13 in immunity and inflammation," Inflammopharmacology, Article ID 1568-5608, 2013.

[51] A. Pardigol, U. Forssmann, H.-D. Zucht et al., "HCC-2, a human chemokine: gene structure, expression pattern, and biological activity," Proceedings of the National Academy of Sciences of the United States of America, vol. 95, no. 11, pp. 6308-6313, 1998.

[52] H. Nomiyama, K. Hieshima, T. Nakayama et al., "Human CC chemokine liver-expressed chemokine/CCL16 is a functional ligand for CCR1, CCR2 and CCR5, and constitutively expressed by hepatocytes," International Immunology, vol. 13, no. 8, pp. 1021-1029, 2001.

[53] T. Sekiya, M. Miyamasu, M. Imanishi et al., "Inducible expression of a Th2-type CC chemokine thymus- and activation-regulated chemokine by human bronchial epithelial cells," Journal of Immunology, vol. 165, no. 4, pp. 2205-2213, 2000.

[54] F. Kusano, Y. Tanaka, F. Marumo, and C. Sato, "Expression of $\mathrm{C}-\mathrm{C}$ chemokines is associated with portal and periportal inflammation in the liver of patients with chronic hepatitis C," Laboratory Investigation, vol. 80, no. 3, pp. 415-422, 2000.

[55] Y. Shimizu, H. Murata, Y. Kashii et al., "CC-chemokine receptor 6 and its ligand macrophage inflammatory protein $3 \alpha$ might be involved in the amplification of local necroinflammatory response in the liver," Hepatology, vol. 34, no. 2, pp. 311-319, 2001.

[56] R. Godiska, D. Chantry, C. J. Raport et al., "Human macrophage-derived chemokine (MDC), a novel chemoattractant for monocytes, monocyte-derived dendritic cells, and natural killer cells," Journal of Experimental Medicine, vol. 185, no. 9, pp. 15951604, 1997.

[57] V. P. Patel, B. L. Kreider, Y. Li et al., "Molecular and functional characterization of two novel human C-C chemokines as inhibitors of two distinct classes of myeloid progenitors," Journal of Experimental Medicine, vol. 185, no. 7, pp. 1163-1172, 1997.

[58] A. P. Vicari, D. J. Figueroa, J. A. Hedrick et al., "TECK: a novel CC chemokine specifically expressed by thymic dendritic cells and potentially involved in T cell development," Immunity, vol. 7, no. 2, pp. 291-301, 1997.

[59] C. A. O’Mahony and J. M. Vierling, "Etiopathogenesis of primary sclerosing cholangitis," Seminars in Liver Disease, vol. 26, no. 1, pp. 3-21, 2006.

[60] A. Shinkai, H. Yoshisue, M. Koike et al., "A novel human CC chemokine eotaxin-3, which is expressed in IL-4- stimulated vascular endothelial cells, exhibits potent activity toward eosinophils," Journal of Immunology, vol. 163, no. 3, pp. 1602-1610, 1999.

[61] N. Xiong, Y. Fu, S. Hu, M. Xia, and J. Yang, "CCR10 and its ligands in regulation of epithelial immunity and diseases," Protein\&Cell, vol. 3, no. 8, pp. 571-580, 2012.

[62] J. Kennedy, G. S. Kelner, S. Kleyensteuber et al., "Molecular cloning and functional characterization of human lymphotactin," Journal of Immunology, vol. 155, no. 1, pp. 203-209, 1995. 
[63] H. Nomiyama, K. Hieshima, N. Osada et al., "Extensive expansion and diversification of the chemokine gene family in zebrafish: identification of a novel chemokine subfamily CX," BMC Genomics, vol. 9, article 222, 2008.

[64] A. M. Fong, L. A. Robinson, D. A. Steeber et al., "Fractalkine and CX3CR1 mediate a novel mechanism of leukocyte capture, firm adhesion, and activation under physiologic flow," Journal of Experimental Medicine, vol. 188, no. 8, pp. 1413-1419, 1998.

[65] A. E. I. Proudfoot, C. A. Power, and T. N. C. Wells, "The strategy of blocking the chemokine system to combat disease," Immunological Reviews, vol. 177, pp. 246-256, 2000.

[66] E. Deutsch, S. A. Johnson, and W. H. Seegers, "Differentiation of certain platelet factors related to blood coagulation," Circulation Research, vol. 3, no. 1, pp. 110-115, 1955.

[67] A. D. Luster, "Mechanisms of disease: chemokines-chemotactic cytokines that mediate inflammation," New England Journal of Medicine, vol. 338, no. 7, pp. 436-445, 1998.

[68] T. J. Schall and K. B. Bacon, "Chemokines, leukocyte trafficking, and inflammation," Current Opinion in Immunology, vol. 6, no. 6, pp. 865-873, 1994.

[69] S. Segerer, Y. Cui, F. Eitner et al., "Expression of chemokines and chemokine receptors during human renal transplant rejection," American Journal of Kidney Diseases, vol. 37, no. 3, pp. 518-531, 2001.

[70] H. Nomiyama, N. Osada, and O. Yoshie, "A family tree of vertebrate chemokine receptors for a unified nomenclature," Developmental and Comparative Immunology, vol. 35, no. 7, pp. 705715, 2011.

[71] J. A. Belperio, M. P. Keane, M. D. Burdick et al., "Role of CXCR2/ CXCR2 ligands in vascular remodeling during bronchiolitis obliterans syndrome," Journal of Clinical Investigation, vol. 115, no. 5, pp. 1150-1162, 2005.

[72] T. El-Sawy, J. A. Belperio, R. M. Strieter, D. G. Remick, and R. L. Fairchild, "Inhibition of polymorphonuclear leukocyte-mediated graft damage synergizes with short-term costimulatory blockade to prevent cardiac allograft rejection," Circulation, vol. 112, no. 3, pp. 320-331, 2005.

[73] G. Cacalano, J. Lee, K. Kikly et al., "Neutrophil and B cell expansion in mice that lack the murine IL-8 receptor homolog," Science, vol. 265, no. 5172, pp. 682-684, 1994.

[74] A. J. M. Lewis, A. J. Rostron, D. M. W. Cork, J. A. Kirby, and J. H. Dark, "Norepinephrine and arginine vasopressin increase hepatic but not renal inflammatory activation during hemodynamic resuscitation in a rodent model of brain-dead donors," Experimental and Clinical Transplantation, vol. 7, no. 2, pp. 119123, 2009.

[75] J. Pratschke, M. J. Wllhelm, M. Kusaka et al., "Brain death and its influence on donor organ quality and outcome after transplantation," Transplantation, vol. 67, no. 3, pp. 343-348, 1999.

[76] O. Kollmar, C. Scheuer, M. D. Menger, and M. K. Schilling, "Macrophage inflammatory protein-2 promotes angiogenesis, cell migration, and tumor growth in hepatic metastasis," Annals of Surgical Oncology, vol. 13, no. 2, pp. 263-275, 2006.

[77] M. Kataoka, H. Shimizu, N. Mitsuhashi et al., "Effect of coldischemia time on C-X-C chemokine expression and neutrophil accumulation in the graft liver after orthotopic liver transplantation in rats," Transplantation, vol. 73, no. 11, pp. 1730-1735, 2002.

[78] A. B. Lentsch, H. Yoshidome, W. G. Cheadle, F. N. Miller, and M. J. Edwards, "Chemokine involvement in hepatic ischemia/ reperfusion injury in mice: roles for macrophage inflammatory protein-2 and KC," Hepatology, vol. 27, no. 4, pp. 1172-1177, 1998.
[79] H. Shimizu, M. Kataoka, M. Ohtsuka et al., "Extended cold preservation of the graft liver enhances neutrophil-mediated pulmonary injury after liver transplantation," Hepato-Gastroenterology, vol. 52, no. 64, pp. 1172-1175, 2005.

[80] C. M. Hogaboam, C. L. Bone-Larson, M. L. Steinhauser et al., "Novel CXCR2-dependent liver regenerative qualities of ELRcontaining CXC chemokines," FASEB Journal, vol. 13, no. 12, pp. 1565-1574, 1999.

[81] Y. Saiman and S. L. Friedman, "The role of chemokines in acute liver injury," Frontiers in Physiology, vol. 3, article 213, 2012.

[82] S. Goddard, A. Williams, C. Morland et al., "Differential expression of chemokines and chemokine receptors shapes the inflammatory response in rejecting human liver transplants," Transplantation, vol. 72, no. 12, pp. 1957-1967, 2001.

[83] W. W. Hancock, B. Lu, W. Gao et al., "Requirement of the chemokine receptor CXCR3 for acute allograft rejection," Journal of Experimental Medicine, vol. 192, no. 10, pp. 1515-1519, 2000.

[84] J. A. Belperio and A. Ardehali, "Chemokines and transplant vasculopathy," Circulation Research, vol. 103, no. 5, pp. 454-466, 2008.

[85] J.-W. Park, M. E. Gruys, K. McCormick et al., "Primary hepatocytes from mice treated with IL-2/IL-12 produce $\mathrm{T}$ cell chemoattractant activity that is dependent on monokine induced by IFN- $\gamma$ (Mig) and chemokine responsive to $\gamma$-2 (Crg-2)," Journal of Immunology, vol. 166, no. 6, pp. 3763-3770, 2001.

[86] H. Obara, K. Nagasaki, C. L. Hsieh et al., "IFN- $\gamma$, produced by NK cells that infiltrate liver allografts early after transplantation, links the innate and adaptive immune responses," American Journal of Transplantation, vol. 5, no. 9, pp. 2094-2103, 2005.

[87] M. G. Krukemeyer, J. Moeller, L. Morawietz et al., "Description of B lymphocytes and plasma cells, complement, and chemokines/receptors in acute liver allograft rejection," Transplantation, vol. 78, no. 1, pp. 65-70, 2004.

[88] N. Mitsuhashi, G. D. Wu, H. Zhu et al., "Rat chemokine CXCL11: structure, tissue distribution, function and expression in cardiac transplantation models," Molecular and Cellular Biochemistry, vol. 296, no. 1-2, pp. 1-9, 2007.

[89] C. R. Bao, G. Y. Tang, X. P. Zhang, and Z. W. Quan, "Lentivirusmediated gene transfer of small interfering RNA against the chemokine receptor CXCR3 suppresses cytokine indicators of acute graft rejection in a rat model," Journal of International Medical Research, vol. 38, no. 3, pp. 1113-1120, 2010.

[90] C. Peralta, M. B. Jiménez-Castro, and J. Gracia-Sancho, "Hepatic ischemia and reperfusion injury: effects on the liver sinusoidal milieu," Journal of Hepatology, vol. 59, no. 5, pp. 1094-1106, 2013.

[91] H. Huang, J. Evankovich, W. Yan et al., "Endogenous histones function as alarmins in sterile inflammatory liver injury through Toll-like receptor 9 in mice," Hepatology, vol. 54, no. 3, pp. 999-1008, 2011.

[92] A. B. Lentsch, A. Kato, H. Yoshidome, K. M. McMasters, and M. J. Edwards, "Inflammatory mechanisms and therapeutic strategies for warm hepatic ischemia/reperfusion injury," Hepatology, vol. 32, no. 2, pp. 169-173, 2000.

[93] J. S. Gujral, T. J. Bucci, A. Farhood, and H. Jaeschke, "Mechanism of cell death during warm hepatic ischemia-reperfusion in rats: apoptosis or necrosis?" Hepatology, vol. 33, no. 2, pp. 397405, 2001.

[94] N. C. Teoh and G. C. Farrell, "Hepatic ischemia reperfusion injury: pathogenic mechanisms and basis for hepatoprotection," Journal of Gastroenterology and Hepatology, vol. 18, no. 8, pp. 891-902, 2003. 
[95] H. Jaeschke, "Mechanisms of liver injury-II. Mechanisms of neutrophil-induced liver cell injury during hepatic ischemiareperfusion and other acute inflammatory conditions," American Journal of Physiology: Gastrointestinal and Liver Physiology, vol. 290, no. 6, pp. G1083-G1088, 2006.

[96] C. N. Clarke, S. Kuboki, A. Tevar, A. B. Lentsch, and M. Edwards, "CXC chemokines play a critical role in liver injury, recovery, and regeneration," American Journal of Surgery, vol. 198, no. 3, pp. 415-419, 2009.

[97] A. Casillas-Ramírez, I. B. Mosbah, F. Ramalho, J. Roselló-Catafau, and C. Peralta, "Past and future approaches to ischemiareperfusion lesion associated with liver transplantation," Life Sciences, vol. 79, no. 20, pp. 1881-1894, 2006.

[98] X. Ren, A. Carpenter, C. Hogaboam, and L. Colletti, "Mitogenic properties of endogenous and pharmacological doses of macrophage inflammatory protein- 2 after $70 \%$ hepatectomy in the mouse," American Journal of Pathology, vol. 163, no. 2, pp. 563570, 2003.

[99] S. Kuboki, T. Shin, N. Huber et al., "Hepatocyte signaling through CXC chemokine receptor-2 is detrimental to liver recovery after ischemia/reperfusion in mice," Hepatology, vol. 48, no. 4, pp. 1213-1223, 2008.

[100] C. Clarke, S. Kuboki, N. Sakai et al., "CXC chemokine receptor1 is expressed by hepatocytes and regulates liver recovery after hepatic ischemia/reperfusion injury," Hepatology, vol. 53, no. 1, pp. 261-271, 2011.

[101] K. M. Olthoff, L. Kulik, B. Samstein et al., "Validation of a current definition of early allograft dysfunction in liver transplant recipients and analysis of risk factors," Liver Transplantation, vol. 16, no. 8, pp. 943-949, 2010.

[102] P. R. Salvalaggio, G. E. Felga, R. C. Afonso, and B. H. FerrazNeto, "Early allograft dysfunction and liver transplant outcomes: a single center retrospective study," Transplantation Proceedings, vol. 44, no. 8, pp. 2449-2451, 2012.

[103] Y. M. W. Janssen-Heininger, M. E. Poynter, and P. A. Baeuerle, "Recent advances towards understanding redox mechanisms in the activation of nuclear factor $\kappa \mathrm{B}$," Free Radical Biology and Medicine, vol. 28, no. 9, pp. 1317-1327, 2000.

[104] W. W. Hancock, L. Wang, Q. Ye, R. Han, and I. Lee, "Chemokines and their receptors as markers of allograft rejection and targets for immunosuppression," Current Opinion in Immunology, vol. 15, no. 5, pp. 479-486, 2003.

[105] B. Sun and M. Karin, "NF- $\kappa$ B signaling, liver disease and hepatoprotective agents," Oncogene, vol. 27, no. 48, pp. 6228-6244, 2008.

[106] J.-D. Wang, N. Nonomura, S. Takahara et al., "Lymphotactin: a key regulator of lymphocyte trafficking during acute graft rejection," Immunology, vol. 95, no. 1, pp. 56-61, 1998.

[107] H. Robertson, A. R. Morley, D. Talbot, K. Callanan, and J. A. Kirby, "Renal allograft rejection: $\beta$-chemokine involvement in the development of tubulitis," Transplantation, vol. 69, no. 4, pp. 684-687, 2000.

[108] N. W. Lukacs, C. Hogaboam, E. Campbell, and S. L. Kunkel, "Chemokines: function, regulation and alteration of inflammatory responses," Chemical Immunology, vol. 72, pp. 102-120, 1999.

[109] H. Li, H.-Y. Xie, L. Zhou et al., "Copy number variation in CCL3L1 gene is associated with susceptibility to acute rejection in patients after liver transplantation," Clinical Transplantation, vol. 26, no. 2, pp. 314-321, 2012.

[110] C. Botella, L. Marín, R. Moya-Quiles et al., "Lack of association between the $-403 \mathrm{G} / \mathrm{A}$ promoter polymorphism in the human
CCL5/RANTES chemokine gene in liver transplant outcome," Transplant International, vol. 19, no. 2, pp. 98-104, 2006.

[111] C. M. Morland, J. Fear, G. McNab, R. Joplin, and D. H. Adams, "Promotion of leukocyte transendothelial cell migration by chemokines derived from human biliary epithelial cells in vitro," Proceedings of the Association of American Physicians, vol. 109, no. 4, pp. 372-382, 1997.

[112] W. M. Baldwin III, C. P. Larsen, and R. L. Fairchild, "Innate immune responses to transplants: a significant variable with cadaver donors," Immunity, vol. 14, no. 4, pp. 369-376, 2001.

[113] E. Akalin and B. Murphy, "Gene polymorphisms and transplantation," Current Opinion in Immunology, vol. 13, no. 5, pp. 572576, 2001.

[114] M. Fischereder, B. Luckow, B. Hocher et al., "CC chemokine receptor 5 and renal-transplant survival," The Lancet, vol. 357, no. 9270, pp. 1758-1761, 2001.

[115] B. Schröppel, M. Fischereder, R. Ashkar et al., "The impact of polymorphisms in chemokine and chemokine receptors on outcomes in liver transplantation," American Journal of Transplantation, vol. 2, no. 7, pp. 640-645, 2002.

[116] L. Fischer-Maas, R. Schneppenheim, F. Oyen et al., "Analysis of the CC chemokine receptor $5 \Delta 32$ polymorphism in pediatric liver transplant recipients," Pediatric Transplantation, vol. 12, no. 7, pp. 769-772, 2008.

[117] W. R. Farid, J. de Jonge, P. E. Zondervan et al., "Relationship between the histological appearance of the portal vein and development of ischemic-type biliary lesions after liver transplantation," Liver Transplantation, vol. 19, no. 10, pp. 1088-1098, 2013.

[118] C. I. Buis, H. Hoekstra, R. C. Verdonk, and R. J. Porte, “Causes and consequences of ischemic-type biliary lesions after liver transplantation," Journal of Hepato-Biliary-Pancreatic Surgery, vol. 13, no. 6, pp. 517-524, 2006.

[119] G. Otto, T. Roeren, M. Golling et al., "Ischemic type lesions of the bile ducts after liver transplantation: 2 years results," Zentralblatt für Chirurgie, vol. 120, no. 6, pp. 450-454, 1995.

[120] R. C. Verdonk, C. I. Buis, E. J. van der Jagt et al., "Nonanastomotic biliary strictures after liver transplantation-part 2: management, outcome, and risk factors for disease progression," Liver Transplantation, vol. 13, no. 5, pp. 725-732, 2007.

[121] F. Frongillo, U. Grossi, A. W. Avolio et al., "Factors predicting ischemic-type biliary lesions (ITBLs) after liver transplantation," Transplantation Proceedings, vol. 44, no. 7, pp. 2002-2004, 2012.

[122] J. M. Langrehr, A. Schneller, R. Neuhaus, T. Vogl, R. Hintze, and P. Neuhaus, "Etiologic factors and incidence of ischemic type biliary lesions (ITBL) after liver transplantation," Langenbecks Archiv für Chirurgie, vol. 115, pp. 1560-1562, 1998.

[123] S. Nishida, N. Nakamura, J. Kadono et al., "Intrahepatic biliary strictures after liver transplantation," Journal of Hepato-BiliaryPancreatic Surgery, vol. 13, no. 6, pp. 511-516, 2006.

[124] G. Fava, S. Glaser, H. Francis, and G. Alpini, "The immunophysiology of biliary epithelium," Seminars in Liver Disease, vol. 25, no. 3, pp. 251-264, 2005.

[125] T. Hinoi, P. C. Lucas, R. Kuick, S. Hanash, K. R. Cho, and E. R. Fearon, "CDX2 regulates liver intestine-cadherin expression in normal and malignant colon epithelium and intestinal metaplasia," Gastroenterology, vol. 123, no. 5, pp. 1565-1577, 2002.

[126] C. Moench, A. Uhrig, A. Wunsch, J. Thies, and G. Otto, "Chemokines: reliable markers for diagnosis of rejection and inflammation following orthotopic liver transplantation," Transplantation Proceedings, vol. 33, no. 7-8, pp. 3293-3294, 2001. 
[127] R. M. Strieter and J. A. Belperio, "Chemokine receptor polymorphism in transplantation immunology: no longer just important in AIDS," The Lancet, vol. 357, no. 9270, pp. 1725-1726, 2001.

[128] S. Op Den Dries, M. E. Sutton, T. Lisman, and R. J. Porte, "Protection of bile ducts in liver transplantation: looking beyond ischemia," Transplantation, vol. 92, no. 4, pp. 373-379, 2011.

[129] Y. Lei and Y. Takahama, "XCL1 and XCR1 in the immune system," Microbes and Infection, vol. 14, no. 3, pp. 262-267, 2012.

[130] A. Bachem, S. Güttler, E. Hartung et al., "Superior antigen crosspresentation and XCR1 expression define human CD11c+ CD141+ cells as homologues of mouse CD8+ dendritic cells," Journal of Experimental Medicine, vol. 207, no. 6, pp. 1273-1281, 2010.

[131] R. A. Kroczek and V. Henn, "The role of XCR1 and its ligand $\mathrm{XCL1}$ in antigen cross-presentation by murine and human dendritic cells," Frontiers in Immunology, vol. 3, no. 14, 2012.

[132] Y. Lei, A. M. Ripen, N. Ishimaru et al., "Aire-dependent production of XCL1 mediates medullary accumulation of thymic dendritic cells and contributes to regulatory T cell development," Journal of Experimental Medicine, vol. 208, no. 2, pp. 383-394, 2011.

[133] K. D. Nguyen, A. Fohner, J. D. Booker, C. Dong, A. M. Krensky, and K. C. Nadeau, "XCL1 enhances regulatory activities of CD4+CD25highCD127low/- T cells in human allergic asthma," Journal of Immunology, vol. 181, no. 8, pp. 5386-5395, 2008.

[134] S. Jung, J. Aliberti, P. Graemmel et al., "Analysis of fractalkine receptor CX3CR1 function by targeted deletion and green fluorescent protein reporter gene insertion," Molecular and Cellular Biology, vol. 20, no. 11, pp. 4106-4114, 2000.

[135] J. K. Harrison, Y. Jiang, S. Chen et al., "Role for neuronally derived fractalkine in mediating interactions between neurons and CX3CR1-expressing microglia," Proceedings of the National Academy of Sciences of the United States of America, vol. 95, no. 18, pp. 10896-10901, 1998.

[136] D. Moatti, S. Faure, F. Fumeron et al., "Polymorphism in the fractalkine receptor CX3CR1 as a genetic risk factor for coronary artery disease," Blood, vol. 97, no. 7, pp. 1925-1928, 2001.

[137] H. E. Wasmuth, M. M. Zaldivar, M.-L. Berres et al., "The fractalkine receptor CX3CR1 is involved in liver fibrosis due to chronic hepatitis C infection," Journal of Hepatology, vol. 48, no. 2, pp. 208-215, 2008.

[138] K. Bourd-Boittin, L. Basset, D. Bonnier, A. L'Helgoualc'H, M. Samson, and N. Théret, "CX3CL1/fractalkine shedding by human hepatic stellate cells: contribution to chronic inflammation in the liver," Journal of Cellular and Molecular Medicine, vol. 13, no. 8, pp. 1526-1535, 2009.

[139] K. R. Karlmark, H. W. Zimmermann, C. Roderburg et al., "The fractalkine receptor CX3CR1 protects against liver fibrosis by controlling differentiation and survival of infiltrating hepatic monocytes," Hepatology, vol. 52, no. 5, pp. 1769-1782, 2010.

[140] T. Aoyama, S. Inokuchi, D. A. Brenner, and E. Seki, "CX3CL1CX3CR1 interaction prevents carbon tetrachloride-induced liver inflammation and fibrosis in mice," Hepatology, vol. 52, no. 4, pp. 1390-1400, 2010.

[141] R. Bertini, L. S. Barcelos, A. R. Beccari et al., "Receptor binding mode and pharmacological characterization of a potent and selective dual CXCR1/CXCR2 non-competitive allosteric inhibitor," British Journal of Pharmacology, vol. 165, no. 2, pp. 436454, 2012.

[142] M. Liu, S. Guo, J. M. Hibbert et al., "CXCL10/IP-10 in infectious diseases pathogenesis and potential therapeutic implications,"
Cytokine and Growth Factor Reviews, vol. 22, no. 3, pp. 121-130, 2011.

[143] R. Bertini, M. Allegretti, C. Bizzarri et al., "Noncompetitive allosteric inhibitors of the inflammatory chemokine receptors CXCR1 and CXCR2: prevention of reperfusion injury," Proceedings of the National Academy of Sciences of the United States of America, vol. 101, no. 32, pp. 11791-11796, 2004.

[144] E. J. Fernandez and E. Lolis, "Structure, function, and inhibition of chemokines," Annual Review of Pharmacology and Toxicology, vol. 42, pp. 469-499, 2002.

[145] M. Miura, X. Fu, Q.-W. Zhang, D. G. Remick, and R. L. Fairchild, "Neutralization of Gro $\alpha$ and macrophage inflammatory protein-2 attenuates renal ischemia/reperfusion injury," American Journal of Pathology, vol. 159, no. 6, pp. 2137-2145, 2001. 


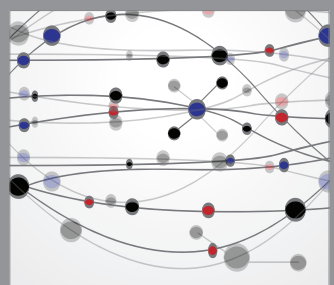

The Scientific World Journal
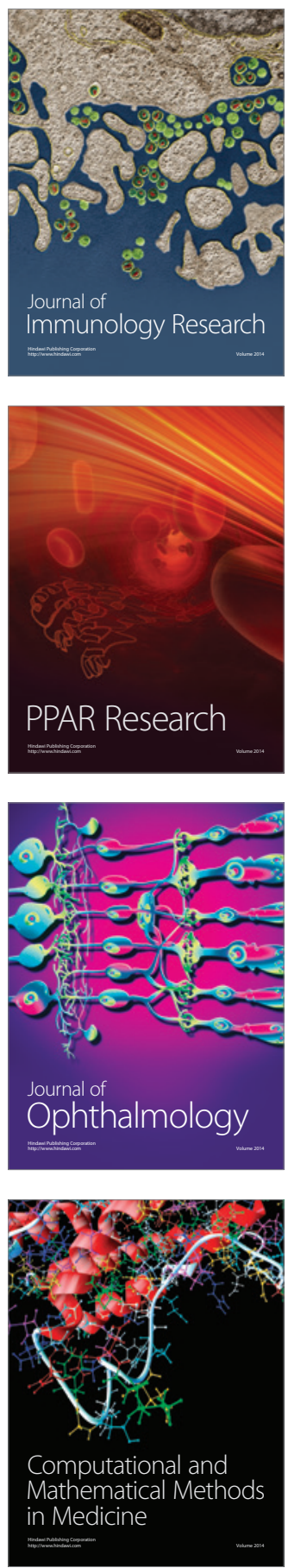

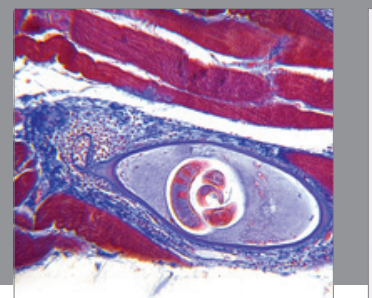

Gastroenterology

Research and Practice
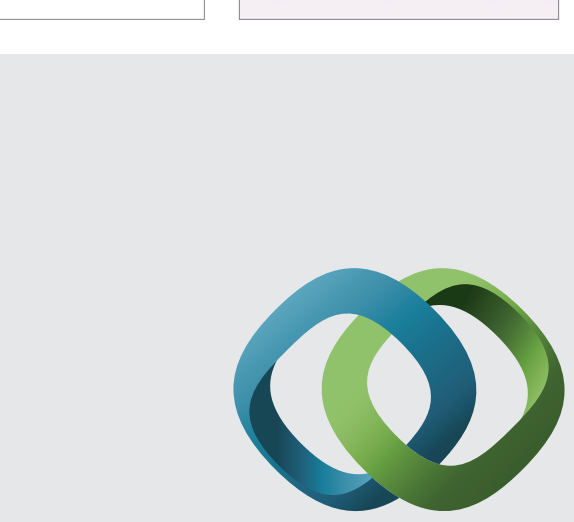

\section{Hindawi}

Submit your manuscripts at

http://www.hindawi.com
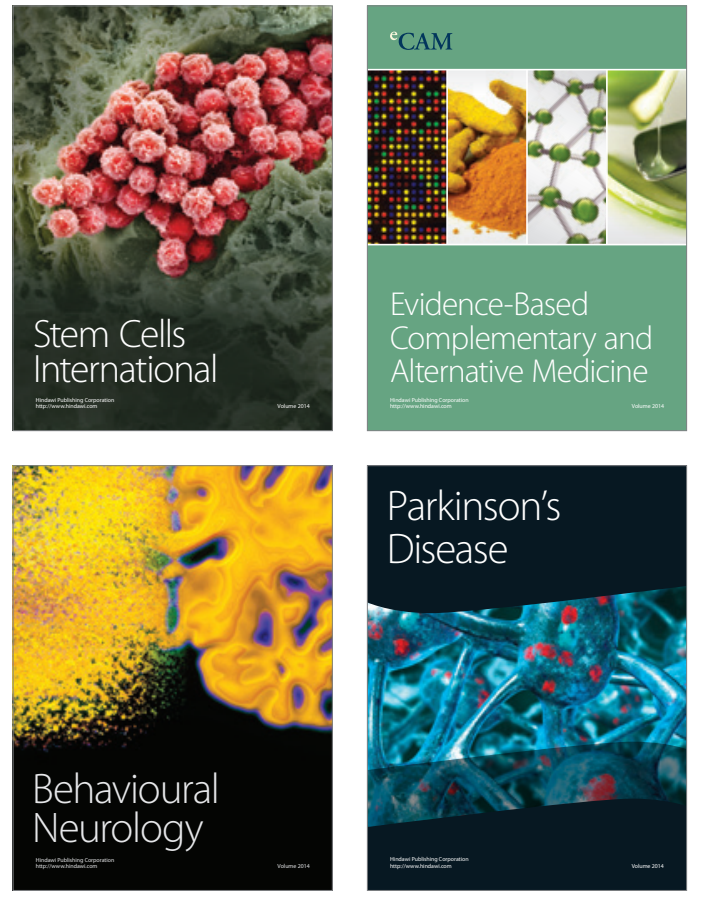
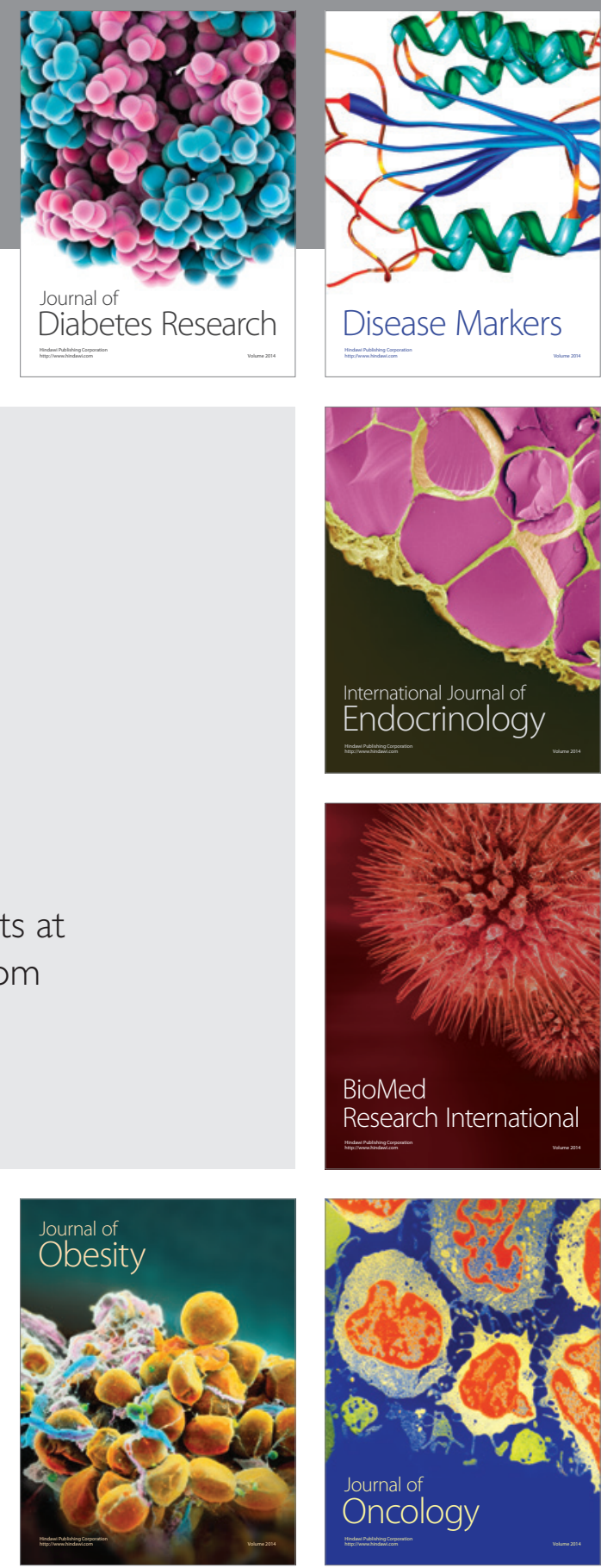

Disease Markers
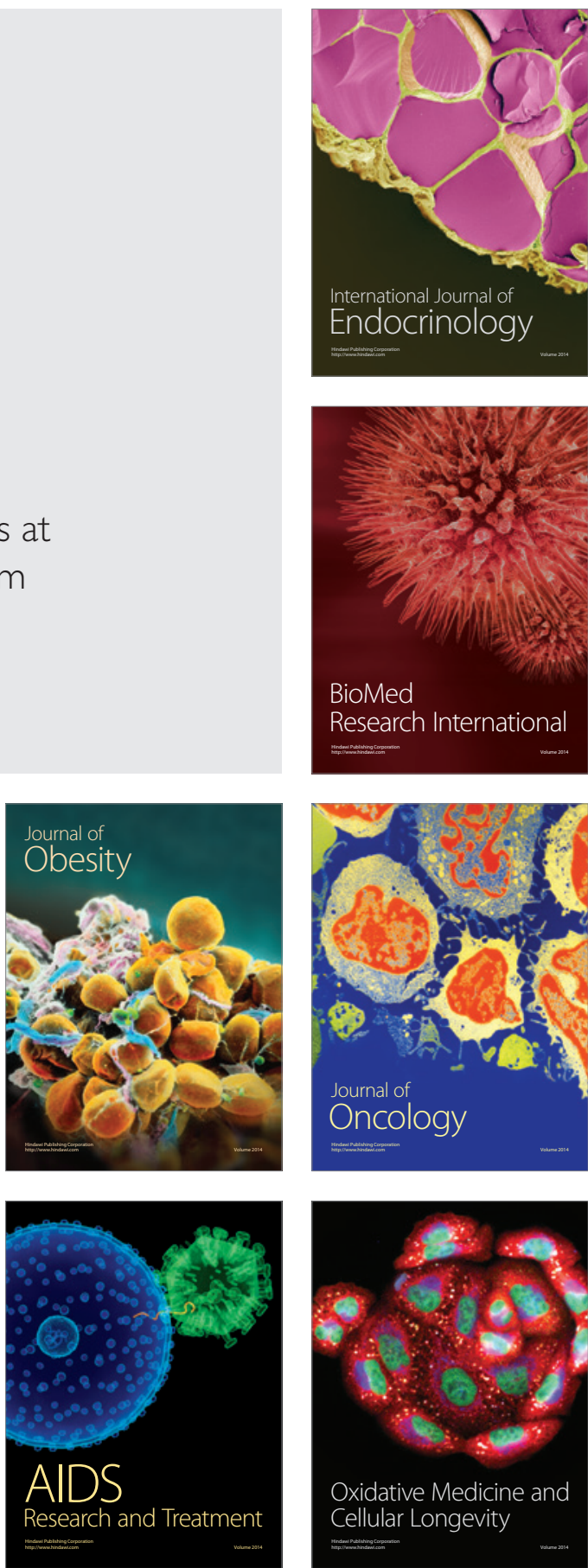